\title{
A VERY SPECIAL REgUlatory Milestone
}

\author{
William S. Laufer*
}

\section{ABSTRACT}

Expenditures underwriting corporate compliance in the United States are approaching a very special regulatory milestone. Compliance costs are nearing municipal policing costs. The trajectory of compliance expenditures over the past several decades may be traced to a good corporate citizenship movement in the mid-1990s where the government proposed a public-private sector partnership to combat corporate crime. In this Essay, it is argued that this "partnership" was never really about a fair sharing the enforcement responsibilities. The government hoped to overcome the near insurmountable challenge of getting evidence of corporate wrongdoing, while shifting as much of the burden and costs of policing to the regulated. Companies continue to justify making compliance expenditures in reasonably defensive ways to levels that are now unprecedented.

The Essay highlights that those who rail against over-criminalization or corporate criminal liability, more generally, miss speaking out against a onesided regulatory strategy of compliance cost shifting that brings us to this historic milestone. Moreover, the threat of unfair and burdensome costs was never with the very rare event of corporate criminal liability. Rather, the threat came from firms taking the government's bait that they needed to spend, and spend, and spend more. This boundless spending, it is concluded, may be seen as imposition of a preemptive penalty on firms. This is a way for regulators to ensure that firms pay a fair share for their wrongdoing for the "dark figure" of corporate culpability.

In this Essay, some of the most significant questions about the private and public administration of justice are asked on the precipice of a gradual retreat from this very special regulatory milestone. This retreat will come from efficiencies brought about by the digitalization of compliance and a

* J.D., Ph.D., Julian Aresty Endowed Professor, Department of Legal Studies and Business Ethics, The Wharton School, University of Pennsylvania; Director, Carol and Lawrence Zicklin Center, The Wharton School, University of Pennsylvania. My appreciation to Vic Khanna, Eric Orts, David Zaring, Peter Conti-Brown, Eduardo Saad-Diniz, Mihailis Diamantis, Steven Solow, and Ron Sarachan for comments on earlier versions of the essay. 
convergence in compliance technology, evaluation science, international standards, and investments in sophisticated enterprise-wide risk management systems. The resulting reduction in compliance expenditures will bring about a corresponding decline in preemptive penalties. The hope is that this will motivate government functionaries to join firms as an active partner in forging new and innovative paths to regulation.

INTRODUCTION 393

I. PUBLIC VERSUS PRIVATE POLICING EXPENDITURES ...................400

A. Disingenuous Partners in Crime Control .........................401

B. "Tease" and "Threat" Regulation ...................................408

C. The Costs of Chasing the Tail of Good Corporate Citizenship..... 410

D. Moral Indignation and a Missing Corporate Victimology

II. THE Role OF THE STATE IN CORPORATE CRIME SPENDING ....415

A. The State's Ambivalence.................................................416

B. A Genuine Partner in Corporate Crime Control ..............417

III. A RETREAT From This Milestone: A COMPLiANCE

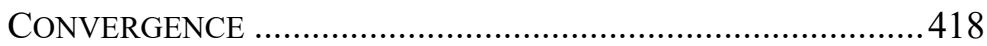

IV. OF PENALTIES, IRONIES, AND EQUIVALENCIES .......................4420

A. A Preemptive Compliance Penalty? ...............................420

B. Irony and Fairness ....................................................423

C. Costs and the Equivalency of Streets and Suites .............424

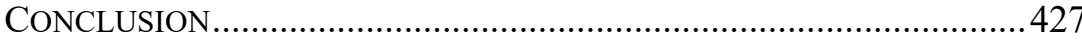

\section{INTRODUCTION}

A regulatory milestone in the United States that seemed impossible to reach nearly a decade ago is now in sight. There soon will be as many enterprise-wide risk, audit, legal, and compliance professionals on the payroll of corporations in the United States as municipal police officers keeping our streets safe. ${ }^{1} \quad$ J.P. Morgan, for example, supports more compliance, risk, and fortress control professionals than all uniformed NYPD officers, and more than three times as many FBI special agents across

1. This milestone is in reach if you add the U.S. Bureau of Labor estimate of 273,000 compliance officers employed in 2016 (available at: https://www.bls.gov/oes/current/oes13 1041.htm [https://perma.cc/CR8K-U97X]) with a modest percentage of the many other risk professionals across the FinTech and RegTech ecosystem. See infra note 20. 
all U.S. field offices. ${ }^{2}$ At the same time, corporate regulatory budgets, in total, appear to dwarf all local, state, and federal law enforcement expenditures. ${ }^{3}$ The regulatory spending at large banks represents up to twenty percent of their operating cost base, making some big city police department budgets look pale, if not anemic. ${ }^{4}$

The primacy of "suite" over "street" hiring and spending should be a milestone of significant symbolic importance for neoconservatives and progressives alike. ${ }^{5}$ Those on the ideological right may justifiably ask whether the private allocation of regulatory and compliance expenditures is reasonable, sustainable, or a product of gross government overreach. Neoconservatives may increase their calls for the abolition of corporate criminal liability with a regulatory state that is already vastly "overcriminalized." Progressives may wonder if corporate wrongdoing is finally being taken seriously, and why public policing expenditures so significantly

2. See 2015 JP Morgan Annual Report 15 (2016) (“Since 2011, our total headcount directly associated with Controls has gone from 24,000 people to 43,000 people, and our total annual Controls spend has gone from $\$ 6$ billion to approximately $\$ 9$ billion annually over that same time period. We have more work to do, but a strong and permanent foundation is in place.”); 2016 JP Morgan Annual Report 71-132 (2017) (discussing the significant expansion of fortress and compliance risk personnel over 2015); NEW YoRK POLICE DEPARTMENT (2017) ("The New York City Police Department (NYPD) is the largest and one of the oldest municipal police departments in the United States, with approximately 36,000 officers.") (http://www1.nyc.gov/site/nypd/about/about-nypd/about-nypd-landing.page

[https://perma.cc/MN8X-MC4L]); FBI QUICK FACTS (2017) (the Federal Bureau of Investigation employs 13,598 special agents) (https://www.fbi.gov/about/mission [https://perma.cc/TZM2-3QGB]).

3. See Curtis W. Copeland, Analysis of an Estimate of the Total Costs of Federal Regulations, Richard N. Marapao and Catherine G. Abulog (eds.) in Federal Regulatory COSTS: ESTIMATES AND ANALYSIS (discussing the costs of federal regulation of companies in terms of tax compliance, economic regulation, occupational safety, environmental protection, health, and homeland security).

4. See, e.g., Matthias Memminger, Mike Baxter, and Edmund Lin, Banking Regtech to the Rescue: Fintech Specialists Can Help Improve Complance, but Banks Should Proceed CAUTIOUSLY 1 (2016) ("We estimate that governance, risk and compliance (GRC) costs account for $15 \%$ to $20 \%$ of the total 'run the bank' cost base of most major banks. And GRC demand drives roughly $40 \%$ of costs for 'change the bank' projects under way.").

5. Thinking about the investment made in corporate versus street crime control seems not only reasonably important, but long overdue. Asking how criminal justice expenditures are made, by whom, and how much, encourages fair suite-to-street comparisons. See infra notes 99 to 104 . Of course, comparing private and public spending on compliance, and the same with street crime, is not any less important. See, e.g., David A. Anderson, The Aggregate Burden of Crime, 42 J. OF L. \& ECON. 611 (1999) (analyzing a study considering the direct and indirect costs of crime on the entire nation, as well as the ancillary costs to the legal system and victims); David A. Anderson, The Cost of Crime, 7 FoundaTIONS AND TRENDS IN MicRoeCONOMics 209 (2011) (analyzing the economic costs of crime in terms of health, opportunity, and government expenditures). A further defense of these comparisons appears infra notes 68 to 72 . 
target our inner-city streets.

Politics aside, the escalation in regulatory expenditures and corresponding burden on corporate treasuries are fairly seen as the consequence of a long honeymoon with the good corporate citizenship movement. This movement comes from a much-heralded partnership between government and the private sector to combat crime unveiled in the early to mid-1990s. ${ }^{6}$ In the wake of the passage of the Sentencing Guidelines for Organizations on November 1, 1991, "good corporate citizens" were tempted into a new and creative partnership with the government to prevent and ferret out corporate wrongdoing. The government exchanged some measure of prosecutorial deference for the voluntary disclosure of wrongdoing, and a now familiar mix of cooperation, investigation, the expression of remorse, and diligent proactive and reactive efforts of firms. ${ }^{7}$

In Part I of this Essay, it is argued that this "partnership" was never really about a fair sharing of the enforcement responsibilities and costs of corporate crime control. It was not about putting in place measures and metrics known to promote ethics, integrity, and good governance. There simply was no body of evidence-based research supporting formal prescriptions for compliance and good citizenship. The government's execution of this partnership was narrowly instrumental: To overcome the near insurmountable challenge of gaining access to inculpatory evidence of corporate wrongdoing, while shifting as much of the burden and costs of policing to the regulated.

The subsequent rise in private law enforcement spending came from a reaction to what may be best called "tease" and "threat" regulation, much of which was tied to crafted disclosures of evidence-empty diligence principles, followed by a somewhat regular pattern of episodic regulatory threats. ${ }^{8}$ These save-face threats were punctuated by much-heralded changes in the United States Department of Justice ("DOJ") and federal agency policies, along with the promotion of being in compliance with The Sarbanes-Oxley

6. William S. Laufer, Integrity, Diligence, and the Limits of Good Corporate Citizenship, 34 AM. Bus. L. J. 157 (1996) (reviewing the history of the citizenship movement).

7. William S. Laufer, Corporate Bodies and Guilty Minds: The Failure of CORPORATE CRIMINAL LIABILITY (2008) (discussing the prescription of due diligence).

8. See Sally S. Simpson, Cycles of Illegality: Antitrust Violations in Corporate America, 65 SOC. FORCES 943, 946 (1986) (suggesting meaningful patterns of antitrust behavior through 1927 to 1981); William S. Laufer and Alan Strudler, Corporate Crime and Making Amends, 44 AM. CRIM. L. REV. 1307 (2007) ("The cyclical history of corporate scandals, resulting in law reforms, active law enforcement, subsequent periods of regulatory laxity, and new scandals, invites the specter of over-criminalization."); William S. Laufer, The Compliance Game, in REGULAÇÃO DO ABUSO NO ÂMBITO CORPORATIVO: O PAPEL DO DIREITO PENAL NA CRISE FINANCEIRA (Saad-Diniz, D. Brodowski \& A. Luiza eds., 2015) (discussing episodic patterns). 
Act of 2002 ("SOX") and the Dodd-Frank Wall Street Reform and Consumer Protection Act of 2010 ("Dodd-Frank"). Exaggerated fears of enforcement follow regulatory change and threats that prompt firms to generously, if not endlessly, spend in support of the status quo of a multi-stakeholder compliance game. It comes as no surprise that this is a game filled with underexplored externalities.

Part II asks questions about one such externality-the discordance between public representations about the priority attached to corporate crime prosecutions and actual public spending. Here it is worth asking why publicsector spending is so dedicated to street-level enforcement, while the hard and soft costs of self-regulation are increasingly, and now disproportionately, borne by businesses. No matter what one thinks of the idea of corporate criminal liability, there is good reason to question the justification for this kind of self-funding in light of the perennial "street crime" targets of state and federal criminal justice expenditures. At the same time, it is not naïve to pose the rhetorical question: What does the overall prioritization of criminal justice expenditures reveal about which criminals and which criminal wrongs are worthy of the state's attention and law enforcement investment? ${ }^{9}$

Complicating any answer to this question is that the costs of selfregulation will likely decrease in the intermediate term. Put aside any possible regulatory retrenchment or systematic deregulation spurred by the White House. ${ }^{10}$ The migration toward the digitalization of compliance, algorithm-based large data aggregation, increasingly sophisticated compliance data analytics and enterprise wide Governance, Risk, and Compliance ("GRC") systems, will soon replace clunky and dated legacy systems and software. ${ }^{11}$ With a convergence in next generation machine

9. Spending on policing our inner cities is both cathartic and instrumental in ways different from corporate criminal law enforcement. A certain kind of moral indignation remains for street crimes and street criminals. A palpable wrongness, absent with corporate offending, drives new place-based policing strategies, creative stop and frisk policies, frequent car stops, and a comfortable churning of street-level drug thugs. See infra notes 94 to 100 .

10. Exec. Order No. 13,771, 82 FR 9,339 (Jan. 30, 2017). Most recently, at the behest of the White House, Citigroup, Barclays, JP Morgan, UBS, and Deutsche Bank were granted long-term waivers for sanctions from the megabank global interest rate scandal, see Exemptions from Certain Prohibited Transaction Restrictions, 89 Fed. Reg. 61, 816 (Dec. 29, 2017).

11. For a consideration of the digitalization of compliance, see, e.g., Gregory Scopino, Preparing Financial Regulation for the Second Machine Age: The Need for Oversight of Digital Intermediaries in the Futures Markets, 2015 Colum. Bus. L. REV. 439 (2015) (describing the financial markets and how artificial intelligence will impact financial regulation); Robert R. Moeller, COSO ENTERPRiSE Risk MANAGEMENT: Establishing Effective Governance, Risk, And Compliance (GRC) Processes (2011) (discussing the 
learning technology, global compliance standards, and even rudimentary evaluation science, longstanding questions about how to monitor, surveil, and measure compliance effectiveness will be addressed in ways that also very efficiently reduce costs while enhancing transparency. ${ }^{12}$

Thus, in Part III, it is concluded that some of the better answers to the most challenging questions raised in this Essay surrounding the private/public administration of justice are offered on the precipice of a retreat from this very special regulatory milestone. This retreat will reaffirm what we have always thought about policing corporate malfeasance: The priority given to elite organizational offending will always give way to the powerful press of society's moral indignation, anger, and abject fear over street crime.

The Essay ends with three critical thoughts about reaching this very special regulatory milestone. Each thought recognizes that firms today invest compliance expenditures to avoid criminal fines at levels that, at times, significantly exceed their exposure risk to sanctions. ${ }^{13}$ Each thought suggests that those who rail against over-criminalization missed speaking out against a one-sided regulatory strategy of compliance cost shifting that

importance of enterprise risk management within the corporate structure, especially as it relates to compliance, risk portfolio, and corporate culture). For a recent survey of how the compliance industry is welcoming Fintech and Regtech, see Stacey English \& Susanna Hammond, Fintech, Regtech and the Role of Compliance 2017, Thomson Reuters (2016) (available at: https://risk.thomsonreuters.com/en/resources/special-report/fintech-regtechand-the-role-of-compliance-2017.html [https://perma.cc/W6TA-E8C6]).

12. See Melanie Swan, BlockChain: Blueprint FOR A New ECONOMY (2015) (discussing the wide-ranging applicability of blockchain technology, including in government functions); Philip Treleaven and Bogdan Batrinca, Algorithmic Regulation: Automating Financial Compliance Monitoring and Regulation Using AI and Blockchain, 45 J. OF FIN. TRANSFORMATION 14 (2017) (discussing the effect artificial intelligence will have on corporate compliance work and the burdensome work of financial regulation); James Bone, The Emergence of a Cognitive Risk Era: Intentional Control Design and Machine Learning, CORPORATE COMPLiANCE Insights, July 17, 2017 (available at: http://www.corporatecomplianceinsights.com/emergence-cognitive-risk-era-intentionalcontrol-design-machine-learning/ [https://perma.cc/QFE7-UZHZ]) (analyzing the effect of automation, machine learning, and situational awareness on the corporate structure).

13. Corporate criminal liability remains a rare event. See Laufer, supra note 7 at 8 ("Before and after the scandals, corporate prosecutions particularly of large, publicly traded entities remain an exception, rare in some jurisdictions and extraordinary in others. Actions against small, privately held companies predominate. But the numbers of cases are still dreadfully small given even conservative estimates of the incidence of corporate crime."). Survey research justifies compliance expenditures not from the risk of criminal sanctions resulting from criminal liability. Rather, if compliance expenditures are justified, it is by the prospects of business disruption, reduced productivity, fees, and other non-legal costs. See Ponemon Inst., The True Cost of Complance, 2 (2011) (available at: http://www.pone mon.org/local/upload/file/True_Cost_of_Compliance_Report_copy.pdf

[https://perma.cc/9ULK-Y3KL]). 
brings us to this historic milestone. And, all three follow from the realization that the threat of unfair and burdensome costs was never with the very rare event of corporate criminal liability, the perennial target of the private sector's ire. The grave threat of unfair and burdensome regulatory costs came from firms taking the government's bait that they needed to spend, and spend more. ${ }^{14}$ This boundless spending, it is concluded, may be seen as imposition of a preemptive penalty on firms. It is a deft way for regulators to ensure that firms pay a fair share for their wrongdoing and, thus, capture the "dark figure" of corporate culpability. ${ }^{15}$

In hindsight, the government conscription of private sector enforcers was a clever stratagem grounded in some very sound regulatory theory. Supporting the Sentencing Commission's Good Citizenship campaign was the conventional scholarly wisdom that self-regulation without the availability of increasingly more formal enforcement mechanisms simply does not work. ${ }^{16}$ A true blend of formal government controls and private informal social controls is required. An enforced self-regulation, in theory, requires the active engagement of the government to assure compliance, at the same time that firms internalize their fair share of enforcement duties and compliance costs. ${ }^{17}$ The motivation for contemporaneous public and private

14. See U.S. Government Accountability Office, Regulatory Burden: MEASUREMENT Challenges and Concerns Raised By Selected Companies (2013) (describing GAO's report on the cumulative effect of federal regulations on certain businesses by analyzing costs and impacts and problematic regulations.); Stacey English and Susanna Hammond, CosTs OF COMPLiANCE 2016, Thomson Reuters (2016) (available at: https://risk.thomsonreut ers.com/content/dam/openweb/documents/pdf/risk/report/cost-compliance-2016.pdf [https://perma.cc/CZA9-QX53]) (sharing the results of Reuters' annual survey analyzing the impact of regulatory change, personal liability, and outsourcing for firms).

15. This may not qualify as a Pigouvian tax in the absence of good measurement or accurate assessment of negative externalities. It does, though, bear some likeness. See Dennis W. Carlton and Glenn C. Loury, The Limitation of Pigouvian Taxes as a Long-Run Remedy for Externalities, 95 Q. J. ECON. 559 (1980) (discussing the theory that Pigouvian taxes alone cannot control externalities); and Dennis W. Carlton and Glenn C. Loury, The Limitation of Pigouvian Taxes as a Long-Run Remedy for Externalities: An Extension of Results, 101 Q. J. ECON. 631 (1986) (building on their previous publication by analyzing the efficiency of constant per unit emission taxes); Arthur Pigou, The Economics OF Welfare 256 (1924) (discussing the principal influences by which the average volume of the national dividend is affected); Kenneth G. Dau-Schmidt, An Economic Analysis of the Criminal Law as a Preference-Shaping Policy, 1990 DuKE L.J. 1 (1990) (offering a preference shaping perspective grounded in optimal penalty theory).

16. For a review of the Sentencing Commission's construction of good citizenship, consider the musings of the two architects of Chapter 8 of the Guidelines (Organizational Guidelines), Ilene H. Nagel \& Winthrop M. Swenson, The Federal Sentencing Guidelines for Corporations: Their Development, Theoretical Underpinnings, and Some Thoughts About their Future, 71 WASH. U. L. Q. 205 (1993) (analyzing the impact of the Sentencing Reform Act and the U.S. Sentencing Commission on corporations).

17. John Braithwaite, Enforced Self-Regulation: A New Strategy for Corporate Crime 
law enforcement was not hidden from leading regulatory theorists: Enforced self-regulation was essential because government ". . . simply cannot afford to do an adequate job on its own." 18

Unfortunately, that part of the script of enforced self-regulation requiring active public-sector investment in developing regulatory capacity and deploying a range of graduated formal and informal controls was not followed. ${ }^{19}$ Instead, successful conscription of private sector "selfregulators" shielded the federal government from sharing partnership costs. At the same time, the government promoted active, if not boundless private sector investment in compliance programming, training, and technology. The idea of a good corporate citizen brought about an increasingly large compliance "machine" doing the lion's share of what was, at least theoretically, the province of both government and private firm enforcement efforts. ${ }^{20}$

A little more than two decades after the birth of this corporate crime control partnership, who would have guessed that private sector regulatory costs would rival the budgets of municipal police departments? ${ }^{21}$ The

Control, 80 MicH. L. REV. 1466 (1982) (discussing the prevalence of corporate crime and how it would be more effective to have self-regulation than to rely on government investigators).

18. Id. at 1467.

19. The importance of regulators in the mix of a private ordering or self-regulatory regime is critical to the efficient building of private sector capacity. See, e.g., Jodi L. Short and Michael W. Toffel, Making Self-Regulation More than Merely Symbolic: The Critical Role of the Legal Environment, 55 ADMIN. ScI. Q. 361, 386 (2010) (“... [H]igh levels of regulatory surveillance at both the field and organizational levels promote the implementation of self-regulation.")

20. This is not to say that regulators fail to contribute at all to this partnership. It is, rather, that the private sector does so overwhelmingly. Compare the resources devoted to compliance data analytics at the SEC versus a single large bank, for example, and the point is made.

21. This milestone considers the total cost of compliance, including consulting, software, staff and training, IT Services, auditing, legal and governance, insurance, and records management across all of the following risk management categories: enterprise-wide risk, capital risk, credit risk, country risk, liquidity risk, market risk, principal risk, compliance risk, conduct risk, legal risk, model risk, operational risk, and reputation risk. Personnel estimates come from publicly available corporate annual reports, where large financial institutions each staff between 20,000 and 45,000 compliance and fortress professionals, and data from the U.S. Department of Labor which reveal the following estimates: financial examiners $(49,750)$; compliance officers $(273,910)$; credit analysts $(72,930)$, and management analysts $(637,690)$. Occupational Employment and Wages, May 2016, BurEAu OF LABOR STATISTICS (Mar. 31, 2017), https://www.bls.gov/news.release/pdf/ocwage.pdf [https://perma.cc/S3S3-GUMU]; cf. Tracey KyCKelhahn, Justice Expenditures AND EMPloyment, FY 1982-2007StATISTICAL TABLES (2011) (breaking down the various expenses and growing trends of the costs of public justice expenditures). This combined pool along with a small percentage of legal staff, audit professionals, and examiners, both in-house and contracted personnel from accountancies, management consultancies, and law firms bring us close to the number of 
language of integrity, good citizenship, and shared responsibility in the 1990s offered no clue as to how costly it would be for firms over time, how alone companies would be in making this investment in private ordering, and how little would be learned about how compliance expenditures actually affect the behavior of agents throughout the corporate hierarchy. ${ }^{22}$

\section{PUBliC VERSUS PRIVATE POLICING EXPENDITURES}

It was a solemn occasion that celebrated the perfect alignment of the public sector's desire for justice and the private sector's willingness to join in on a mission for responsible corporate citizenship. The nearly 500 attendees of the United States Sentencing Commission's ("Sentencing Commission") conference on Corporate Crime in America: Strengthening the "Good Citizen" Corporation on September 7, 1995 would hear something so very comforting: Those in the business community now have a trusted partner in self-policing. ${ }^{23}$ The charge by Judge Richard P. Conaboy, Chairman of the Sentencing Commission, was normative and inspirational:

You must take on the obligation to lead this effort, to be in the

sworn police officers in the U.S. $(750,000)$. Reaching this milestone assumes a continued modest rise in compliance hiring. Consider that LinkedIn now averages approximately 706,000 listings of compliance positions. https://www.linkedin.com/jobs/compliance-jobs/ [https://perma.cc/2VNZ-WK3Y] (last visited Nov. 15, 2017). Notably, this critique of compliance spending and staff does extend to the Securities and Exchange Commission (SEC), but with some notable qualifications. The SEC does commit a sizable percentage of their budget to ensuring regulatory compliance and invests an increasing amount to support compliance data analytics among other important IT initiatives, such as redesigning the Electronic Data Gathering, Analysis and Retrieval (EDGAR), improving examinations through risk assessment and surveillance tools, enhancing the Tips, Complaints, and Referral system (TCR), and improving enforcement investigation and litigation tracking. Unfortunately, their budget is woefully inadequate, at least compared to the private sector they oversee, and supports slightly more than 1,300 enforcement staff and 1,000 compliance personnel. See SECURITIES AND ExCHANGE Comm'n, FY 2017 CONGRESSIONAL BUdGET JUSTIFICATION (2016) at *14, https://www.sec.gov/abou t/reports/secfy 17 congbudgjust.pdf [https://perma.cc/FXQ6-7KSS] (listing the various SEC employment numbers).

22. For a glimpse of how little is known about effective strategies for corporate crime control, see Natalie Schell-Busey, Sally S. Simpson, Melissa Rorie, \& Mariel Alper, What Works? A Systematic Review of Corporate Crime Deterrence, 15 CRIMInology \& PuB. POL'Y. 387, 410 (2016) (asserting that more studies are needed to determine how to effectively deter corporate crime).

23. Proceedings of the Second Symposium on Crime and Punishment in the United States, on Corporate Crime in America: Strengthening the "Good Citizen" Corporation (Sept. 7-8, 1995), (found at http://www.ussc.gov/sites/default/files/pdf/research-and-publicatio ns/research-projects-and-surveys/economic-crimes/19950907symposium/WCSYMPO_opt.pdf [https://perma.cc/8A2M-7GBS]). 
forefront, not only by working to ensure that your companies' employees follow the law but by embracing and placing at the very top of your companies' priorities the basic good citizenship values that make law abidance possible. ${ }^{24}$

In exchange, the government offered the business community some basic due diligence principles that would serve firms well in attempting to mitigate any possible investigation and adjudication of wrongdoing. ${ }^{25}$ No one ever imagined such a large and sweet carrot: Compliance expenditures would be considered in the discretionary calculus of prosecutors to proceed criminally against a corporation. For more than a decade following their passage, being "in compliance" with the Commission's Sentencing Guidelines for Organizations was code for adhering to the text and subtext of a well-settled prescription for good corporate citizenship. ${ }^{26}$ It is not an overstatement that this government-sponsored conference several decades ago marked the beginning of a new partnership between business and government - or so it seemed.

\section{A. Disingenuous Partners in Crime Control}

Architects of enforced self-regulation envisioned a regulatory world that recognized the superiority of firms to self-police under the watchful eyes

24. Id. at 8,10 .

25. See id. at 41 (offering standards to serve as a starting point for companies seeking to develop corporate crime control policies).

26. The history of this partnership predates the Sentencing Commission's work on organizational offenses. Consider that in 1986 the Blue Ribbon Commission on Defense Management (the Packard Commission), organized behind the Defense Industry Initiative (DII), called for a renewed corporate self-governance, commitment to industry-specific codes of conduct, and development of internal controls so as to ensure public confidence in the defense industry. The DII sought to increase the awareness of and commitment to business ethics, including the adoption of codes of ethics and conduct, ethics orientation and training, a mechanism (such as a hotline) to surface concerns about corporate compliance, and procedures for voluntary disclosure of violations of federal laws. Thus, the Sentencing Commission inherited a prescription for corporate self-governance, the creation of codes, internal disciplinary mechanisms, and internal controls that surely influenced their work on the development of Chapter Eight principles. See Laufer, supra note 6, at 161 (explaining that the kind of organizational due diligence outlined in the Sentencing Guidelines has a foundation in agency theory and corporate governance laws); see also Amitai Etzioni, The U.S. Sentencing Commission on Corporate Crime: A Critique, 525 AnNALs AM. ACAD. 147, 149-50 (1993) (asserting that the failure of the Sentencing Commission to consider political forces threatened to undermine its recommendations). For a review of the progress of post guidelines cases, see Cindy R. Alexander, Jennifer Arlen \& Mark A. Cohen, Regulating Corporate Criminal Sanctions: Federal Guidelines and the Sentencing of Public Firms, 42 J.L. \& ECON. 393 (1999). 
of the government. ${ }^{27}$ The design included an active monitoring role for government, agreeing to specific firm conduct rules, and responding with causes of action for non-compliance in increasingly formal and punitive ways. ${ }^{28}$ In hindsight, though, it is clear that this was never a true partnership. Success hinged on a significant government investment in regulatory capacity to keep pace with private sector spending on the management of a wide range of legal, regulatory, governance, and compliance risks. ${ }^{29} \mathrm{~A}$ reasonably proportionate public investment in enterprise risk management systems or compliance data analytics was simply not made. And leadership pushing evidence-based research rather than evidence-empty prescriptions for good corporate citizenship was nowhere to be found. ${ }^{30}$

What does it mean that the private sector effort to coordinate and oversee self-policing was not met with a comparable public sector engagement? Public sector strategy was then, as it is now, all about shifting the costs of corporate criminal law enforcement to the deepest private pocket while, at the same time, prying open a window into the corporate form for inculpatory evidence. There, when and where non-compliance surfaced, the private "partner" in crime control would be incentivized to spend more compliance dollars. Government functionaries, without an obligation to define what it means to have an effective compliance program, could simply moderate the need for additional compliance expenditures - a key proxy for organizational due diligence. ${ }^{31}$ With this kind of strategic cost shifting, it is

27. See generally IAN AyRes \& JOHn BraithWAite, Responsive Regulation: Transcending the Deregulation Debate (1992) (offering the definitive statement on the theory of responsive regulation).

28. See, e.g., Robyn Fairman \& Charlotte Yapp, Enforced Self-Regulation, Prescription, and Conception of Compliance within Small Businesses: The Impact of Enforcement, 27 L. \& POL'Y 491, 497 (2005) (arguing that punishments should first be informal and gradually advance to more formal levels if the company remains non-compliant); Vibeke Lehmann Nielsen \& Christine Parker, Testing Responsive Regulation in Regulatory Enforcement, 3 REG. \& GOVERNANCE 376, 381 (2009) (suggesting that the regulator's use of formal, coercive enforcement methods should correlate with the alleged offender's willingness to cooperate).

29. See generally William S. Laufer, Corporate Liability, Risk Shifting, and the Paradox of Compliance, 52 VAND. L. REV. 1341 (1999) (discussing how regulation was orchestrated to shift the costs and risks of entity liability).

30. For a comparison between estimated private and public compliance staffing costs, see SOCIETY FOR CORPORATE COMPLIANCE AND ETHICS, STAFFING AND BUdGeT BENChMARKING GUIDANCE SURVEY (2016), (available at: http://www.corporatecomplian ce.org/Portals/1/PDF/Resources/Surveys/scce-2016-benchmarking-guidance-surveyreport.pdf?ver=2016-06-15-075138863 [https://perma.cc/4HXG-LWFM]).

31. See United States Sentencing Commission, supra note 23, at 120 (suggesting that government officials have a duty to coordinate their enforcement measures); U.S. Dep't of Justice, Criminal Div. Fraud Section, Evaluation of Corporate Compliance Programs (2017) (stating after more than twenty-five years, criteria to evaluate the effectiveness of compliance program were recently made public). 
little wonder that private expenditures now approach, if not eclipse, public funding of street crime enforcement. ${ }^{32}$

Judge A. David Mazzone introduced the keynote speaker at this Commission conference, Senator Edward Kennedy, with more than a hint of transparency. "Today, when government talks about downsizing, budget complaints, and withdrawing, it's even more important to understand and to promote the role that the 'good citizen' corporation will play in the United States." ${ }^{\prime 3}$ His words now seem all too self-serving: Good corporate citizens will achieve compliance — become compliant — by spending on compliance in ways that provide a certain kind of relief for the government.

To Kennedy's great credit, his lunch-time address expressed concerns with the authenticity of the private sector's commitment to compliance. Kennedy opined:

In a very real sense, the success of the new policy rests with you ... and with many like you across the country. Members of the business community and those who counsel corporate clients must recognize that there will always be skepticism about a policy that gives any break to corporations that have committed crimes, as the guidelines will sometimes do when a corporation demonstrates a solid compliance program. That skepticism will grow if the public comes to believe that companies are approaching the guidelines with a 'window dressing' compliance effort and a clever law firm waiting in the wings at the first sign of trouble. ${ }^{34}$

Kennedy called on businesses to embrace compliance in genuine and authentic ways. But, alas, very little came from this aspirational embrace. This was a shallow grasp not only because some firms, it soon became apparent, beautifully dressed and adorned their windows. It was shallow, in large part, because prosecutors and regulators simply failed to deliver in their more substantive partnership responsibilities. ${ }^{35}$ The long iteration of federal

32. There is an active academic discussion about whether there are enough resources allocated to police inner cities. See generally Aaron Chalfin \& Justin McCrary, Are U.S. Cities Underpoliced?: Theory and Evidence (Univ. of Pa. Dep't of Criminology, Working Paper No. 2016-7.0, 2015) (suggesting that U.S. cities are under-policed). The argument advanced in this Essay does not turn on whether we are moving in the direction of an optimal allocation of criminal justice expenditures. Rather, the concern here is with the responsibility of the State in corporate crime spending.

33. United States Sentencing Commission, supra note 23, at 115.

34. Id. at 119-20.

35. The betrayal of partnership responsibilities came about from a failure by the state to initiate and maintain an investment in compliance capacity, a failure that continues to this day. This responsibility to lead the regulated is not fully captured by aggregated regulatory cost data. For a discussion of the disaggregation of regulatory and compliance costs, with 
prosecutorial guidelines, from Holder, McNulty, and Thompson to Filip were no substitutes for building regulatory capacity. ${ }^{36}$ These prescriptions for prosecutors did little to guide a business community desperate for something more than a due diligence or good governance prophylaxis. All that the white collar bar received was a slightly revised set of guidelines lifted from Chapter 8 of the United States Sentencing Commission. It was, alas, an invitation for a new line of revenue and, for firms, another long invoice.

Not much more need be said of the heralded Yates Memoranda from DOJ prescribing individual liability before any prosecutorial resort to corporate liability. ${ }^{37}$ Yates pushed the prosecutorial pendulum back to where it once was, but to what end? Were there too many corporate prosecutions? ? $^{38}$ Too few individual prosecutions? ${ }^{39}$ Were firms not taking the prescriptions

some comparative data (U.K. and U.S.). See Julian R. Franks, Stephen M. Schaefer, \& Michael D. Staunton, The Direct and Compliance Costs of Financial Regulation, $21 \mathrm{~J}$. BANKING \& FIN. 1547 (1997). For a U.S.-centered analysis of regulatory costs with a separate analysis by firm size and sector, see Copeland, supra note 3; see also Robert W. Hahn \& John A. Hird, The Costs and Benefits of Regulation: Review and Synthesis, 8 YALE J. ON REG. 233, 259 (1991) (providing a comprehensive study and analysis concluding that the benefits of social regulation outweigh the costs by only a small margin).

36. See Memorandum from Eric H. Holder, Jr., Deputy Att'y Gen., U.S. Dep't of Justice, to Heads of Dep't Components \& U.S. Att'ys, on Principles of Federal Prosecution of Business Organizations (June 16, 1999) (providing guidance to prosecutors about the factors to consider before charging a company); Memorandum from Larry Thompson, Deputy Att'y Gen., U.S. Dep't of Justice, to Heads of Dep't Components \& U.S. Att'ys, on Principles of Federal Prosecution of Business Organizations (Jan. 20, 2003) (providing a revised set of principles to guide prosecutors deciding whether to charge a company of wrongdoing); Memorandum from Paul J. McNulty, Deputy Att'y Gen., U.S. Dep't of Justice, to Heads of Dep't Components \& U.S. Att'ys, on Principles of Federal Prosecution of Business Organizations (Dec. 16, 2006) (revising and superseding the guidance issued by Deputy Attorney General Larry Thompson); Memorandum from Mark R. Filip, Deputy Att'y Gen., U.S. Dep't of Justice, to Heads of Dep't Components \& U.S. Att'ys, on Principles of Federal Prosecution of Business Organizations (Aug. 28, 2008), (available at http://www.jus tice.gov/dag/readingroom/dag-memo-08282008.pdf [https://perma.cc/M3YK-52XB]) (revising further the guidance set forth by Deputy Attorney General Paul McNulty).

37. See Memorandum from Sally Quillian Yates, Deputy Att'y Gen., U.S. Dep't of Justice, to Heads of Dep't Components \& U.S. Att'ys, on Individual Accountability for Corporate Wrongdoing (Sept. 9, 2015), http://www.justice.gov/dag/file/769036/download [https://perma.cc/FEG2-PCQC] (establishing principles for the Department of Justice based on the premise that individual accountability is an effective method to combat corporate misconduct).

38. See TracReports, Justice Department Data Reveal 29 Percent Drop in Criminal Prosecutions of Corporations (Oct. 13, 2015), http://trac.syr.edu/tracreports/crim/406/ [https://perma.cc/63KH-DY5G] ("Despite repeated claims to the contrary by top officials at the U.S. Department of Justice, the government's criminal prosecution of corporate violators has declined substantially in the last decade, falling by almost one third (29\%) between FY 2004 and FY 2014.").

39. See TracReports, White Collar Crime Convictions Continue to Decline (Apr. 7, 
seriously? Without any investment in building regulatory capacity, Yates simply ushered in more firm spending on the pretext that individualized prosecutions were now the preferred path for "doing justice." Finally, in such sharp contrast to the extraordinary burden placed on corporations, there was barely a hint of sharing and partnering costs in the compliance scripts of SOX and Dodd-Frank. ${ }^{40}$ The same may be said of the DOJ's most recent guidance on the evaluation of corporate compliance programs. Like all of the other nods and winks about what really matters to prosecutors, this is nothing more than an additional round in a pretend game of evaluation science with an ultracrepidarian's hand. ${ }^{41}$

Regulators tease the regulated with rudimentary prescriptions for diligence that appear to be literally ripped from the pages of introductory management textbooks and business airport books. ${ }^{42}$ Focus on corporate

2016), ("Federal white collar prosecutions reached a 20 -year historic low last year, and there is still an ongoing slide in both prosecutions and convictions.") (available at: http://trac.syr.edu/tracreports/crim/421/ [https://perma.cc/JMK7-L3MM]).

40. Consider, though, the enormous private sector burden. See e.g., Daniel M. Gallagher, Comm'r, Sec. \& Exch. Comm'n, Remarks at the 2013 National Compliance Outreach Program for Broker-Dealers (Apr. 9, 2013) (transcript available at: https://www.sec.gov/news/speech/2013-spch040913dmghtm [https://perma.cc/ZS35-DP3Q ]) ("New rules proposed or implemented by the SEC, CFTC, and other agencies pursuant to the Dodd-Frank Act have already tremendously increased burdens on compliance departments throughout the securities industry. For example, last year, the House Financial Services Committee estimated that it will take 24 million man hours every year in order for the private sector to comply with Dodd-Frank rules."); see also Michael D. Greenberg, For Whom the Whistle Blows: Advancing Corporate Compliance and Integrity Efforts in the Era of Dodd-Frank at 3-4 (2011), http://www.rand.org/pubs/conf_proceedings/CF290.html [https://perma.cc/5WJX-HLBK] (explaining that the purpose of a RAND symposium was to consider the value of internal reporting programs).

41. See U.S. Department of Justice Criminal Division, Fraud Section Evaluation of Corporate Compliance Program, https://www.justice.gov/criminal-fraud/page/file/937501/ download [https://perma.cc/QJH4-CC4B] (providing a framework for evaluating corporate compliance programs); Ronald H. Levine \& Carolyn H. Kendall, The DOJ's New Parameters for Evaluating Corporate Compliance Programs, LAw Journal NewsLetters, July 2017 (explaining that the parameters of the compliance program evaluation memorandum are extensive in scope, containing over one hundred questions for the DOJ to ask); U.S. Dep't of Justice, supra note 31 (providing a framework for evaluating corporate compliance programs). For an excellent review of the challenges of evaluating compliance, see generally Christine Parker \& Vibeke Nielsen, The Challenge of Empirical Research on Business Compliance in Regulatory Capitalism, 5 ANN. ReV. L. \& Soc. SCI. 45 (2009).

42. For an excellent review of the challenges of compliance measurement, see CHRISTINE Parker, The Open Corporation: EFFective Self-Regulation and Democracy (2002) (laying out an innovative framework for successfully building management systems for selfregulation); see also Christine Parker and Vibeke L. Nielsen, Corporate Compliance Systems: Could They Make Any Difference?, 41 ADMIN. \& Soc. 3 , 3 (2008) (demonstrating, through survey data, that commitment to compliance is more important than the compliance system itself). 
culture and the tone at the top. Ensure that corporate leadership drives organizational integrity. Be proactive and appropriately reactive about ethics. Give whistleblowers a means of communication. Hire ethics officers with direct report to senior management and the board of directors. And when there are compliance failures, enforce internal violations of codes of ethics with appropriate disciplinary mechanisms.

When firms made a reasonable investment in new compliance systems, technology, and training, and there were failures, corporate fraud cases were disposed of with increasingly large criminal fines and, by prescription, commitments for additional compliance hiring and expenditures. ${ }^{43}$ The regulatory recipe could not be wrong, even in the absence of any empirical evidence. More and then more of the same compliance ingredients are required. Over the past several years, and after decades of cooking with the same regulatory recipe, the compliance budgets of the largest companies for individual legal risk areas, such as anti-money laundering, are well in the billions. When all risk areas are aggregated, the regulatory spend for large financial institutions, for example, is nothing short of astronomical. ${ }^{44}$

It is regrettable that public partners in corporate crime control who asked for all of this spending are not systematically examining the integrity

43. See Laufer, supra note 29 (discussing the critical role of compliance expenditures). See also Sean J. Griffith, Corporate Governance in an Era of Compliance, 57 WM. \& MARY L. REV. 2075, 2134 (2016) (advocating for decreased government involvement in compliance, and increased disclosures).

44. See U.S. Government Accountability Office, supra note 14; English and Hammond, supra note 14 (describing increased regulatory spending); see also Gregory Elliehausen, The Cost of Bank Regulation: A Review of the Evidence, 84 FED. RES. Bull. 252, 252 (1998) (finding that the cost of all bank regulations amounted to roughly $12 \%$ of non-interest expenses for banks in 1991); James A. Millar and B. Wade Bowen, Small and Large Firm Regulatory Costs: The Case of the Sarbanes-Oxley Act, 11 CORP. GovernANCE 161, 166 (2011) (sharing the results of an empirical test which showed that audit fees were statisticallysignificantly higher after the passage of Sarbanes-Oxley); Franks, supra note 35, at 1549 (referencing multiple studies which show that the cost of regulations are roughly ten-billion dollars per year in the U.S. banking industry). But $c f$. Winston Harrington, Richard D. Morgenstern, and Peter Nelson, On the Accuracy of Regulatory Cost Estimates, 19 JouRNAL OF Policy ANALYSIS AND MANAgEMENT 297, 300 (2000) (noting that aggregating areas of regulatory spending can lead to overestimations of regulatory cost). For a right critique of regulatory costs, see James L. Gattuso \& Diane Katz, Regulation: Killing Opportunity, THE HERITAGE FOUNDATION (October 21, 2014), http://www.heritage.org/governmentregulation/report/regulation-killing-opportunity [https://perma.cc/Q2DV-UE94] (discussing how the exponential increase in the number of regulations has been accompanied by a large increase in regulatory costs); see also William S. Laufer, Compliance and Evidence: Glimpses of Optimism from a Perennial Pessimist, in DiE Verfassung MODERnER STRAFreC HTSPFlege: ERINNERUNG AN JoAChim Vogel 423, 425-26 (K. Tiedemann, U. Sieber, H. Satzger, C. Burchard, \& D. Brodowski eds., 2016) (reasoning that advances in compliance measurement and global enterprise-wide compliance standards could alter compliance practices) 
of integrity programs or the effectiveness of "effective" compliance programs with evidence-based measures. ${ }^{45}$ Public partners are all but mute on the need for literally tens of thousands of compliance, risk, and audit professionals on the payroll of a single bank. And who really knows what kind of changes in employee behavior, if any, are actually brought about by our wholesale investment in ethics, integrity, and compliance training. Public partners promoting private compliance expenditures are not spending enough on leading edge compliance data analytics or coming close to leveraging the promise of large data. ${ }^{46}$ Public partners are not investing billions of dollars to migrate from their entrenched legacy systems to the latest monitoring and surveillance technologies. Partners who demand unbridled compliance expenditures from firms show little to no interest in adopting the kind of real-time co-regulatory and plural regulatory systems with the private sector - or regulators in other sovereignties - that are simply around the bend. Technology, along with decentered and plural conceptions of regulation, holds great promise for a new generation of real partners committed to corporate crime control. ${ }^{47}$ Sadly, only one partner is seriously thinking about and aggressively spending on its regulatory future. ${ }^{48}$

This is regrettable for many reasons including the fact that, as with underwriting the costs of law enforcement with street crime, being an active regulatory partner here is an integral part of the government's

45. One "expert" was simply not enough capacity to evaluate and promulgate evidencebased metrics for regulatory capacity. Cf. Department of Justice, New Compliance Counsel Expert Retained by the DOJ Fraud Section, September 3, 2015 (available at https:/www.justice.gov/criminal-fraud/file/790236/download [https://perma.cc/3SJLTMXT]) (showing the need to hire an additional expert); Sue Reisinger, Hui Chen's Last Day as Compliance Counsel to DOJ, Inside Counsel, June 26, 2017 (available at: http://www.insidecounsel.com/217/06/26/hui-chens-last-day-as-compliance-counsel-to-doj [https://perma.cc/9W69-AWRG]) (noting that Chen has trained many attorneys in the DOJ and that it will still be necessary to replace her).

46. There are, admittedly, a handful of agencies determined to capture rampant fraud and abuse with compliance data analytics, from the Department of Health and Human Services to the Securities and Exchange Commission. See, e.g., Data Analytics to Address Fraud and Improper Payments (2017), (available at: https://www.gao.gov/assets/690/68 3859.pdf [https://perma.cc/FG5F-LDC2]) (summarizing a forum, convened by the Comptroller General of the U.S., dedicated to the use of data analytics to address fraudulent payments). These efforts, however, are so significantly eclipsed by private sector spending. See Short and Toffel, supra note 19 (discussing private sector investment and the absence of public sector enforcement).

47. See Kenneth A. Bamberger, Technologies of Compliance: Risk and Regulation in a Digital Age, 88 TEX. L. REV. 669, 672 (2010) (exploring some of the challenges associated with technology in compliance).

48. See Ann Dryden Witte \& Robert Witt, What We Spend and What We Get: Public and Private Provision of Crime Prevention and Criminal Justice, 22 FisCAL STUD. 2 (2001) (discussing worldwide spending on police and crime prevention more generally). 
responsibility. ${ }^{49}$ Conventional theories of economic regulation turn, at least in part, on the fact that "... regulation is instituted primarily for the protection and benefit of the public at large. ..."50 Leaving an unreasonable share of this task to the private sector fails to fully recognize, embrace, and discharge this dual responsibility. ${ }^{51}$ Moreover, any sense of responsibility is made that much more important by the fact that firms were explicitly offered an active partner in crime control. ${ }^{52}$

\section{B. "Tease" and "Threat" Regulation}

It is perhaps unfair to speak of a betrayal of the public partner to corporate crime control without also questioning the motives, interests, and actions of its private partners - and any regulatory arbitrage. ${ }^{53}$ Admittedly, corporations and other parties are complicit in keeping this partnership as it is. Elsewhere, I speak of the public-private sector compliance relationship as a multi-stakeholder game. ${ }^{54}$ Here stakeholders seek to protect and enhance their positions while minimizing any compromise of the regulatory

49. This responsibility is not discharged by the overall demands on agencies that come from complex reform legislation, including rulemakings and implementation costs. The same can be said of cooperation policies that incentivize corporate disclosures. See, e.g., SEC Commodity and Securities Exchanges, 17 C.F.R. $§ 202.12$ (2000) (announcing an analytical framework to be used when evaluating the cooperation of individuals). For a critical commentary on the trading of cooperation for due diligence credit, see William S. Laufer, Corporate Prosecution, Cooperation, and the Trading of Favors, 87 IowA L. REv. 643 (2002) (questioning the fairness of trading cooperation for government favors, amidst an otherwise positive partnership between corporation and government).

50. George J. Stigler, The Theory of Economic Regulation, 21 THE BELL J. OF ECON. AND MGMT. SCI. 3, 3 (1971).

51. What does it say when shareholders assume the costs of corporate compliance and taxpayers fund the policing of street crime? See Dryden, supra note 48 (considering the relative role of public and private sectors in crime control and criminal justice); see also Mark A. Cohen, Roland T. Rust, \& Sara Steen, Prevention, Crime Control or Cash? Public Preferences Towards Criminal Justice Spending Priorities (Richard H. Smith Sch. of Bus. Working Paper No. RHS-06-048, 2005), https://papers.ssrn.com/sol3/papers.cfm?abstr act id=762626 [https://perma.cc/VDM4-RP95] (exploring the public's priorities on spending).

52. See United States Sentencing Commission, supra note 23, at 359 ("The new policy is fair and provides opportunities for the agency and the regulated community to work together to ensure compliance. This is a partnership that can only thrive when communication is open and frank.").

53. See Victor Fleischer, Regulatory Arbitrage, 89 TEX. L. REV. 227, 229 (2010) (“. . . the most effective techniques [of regulatory arbitrage] are more pernicious, crafted by lawyers to meet the letter of the law while undermining its spirit, successful only until the government discovers and closes the loophole.").

54. See Laufer, supra note 49 (discussing the bargained for trades in the public-private regulatory partnership). 
equilibrium. This is more of a match of posturing and appearances with rules that spare the largest firms from prosecution due to the possibility of systemic risk. This is a game where large firms whose prosecution does not pose a system risk receive crafted plea agreements. Rarely and episodically, symbolic prosecutions of high profile defendants are sought to assuage concerns over market fairness. And small firms, those with far less access to compliance counsel, are more likely to be prosecuted to conviction. ${ }^{55}$

This is a game that seeks optimal compliance expenditures to minimize liability risks while giving players needed moral cover and an appearance of legitimacy. ${ }^{56}$ In this game it is practically impossible for regulators and prosecutors to make meaningful distinctions between and among ethical leaders and laggards, between compliant and non-compliant firms. In fact, one of many remarkable results of this game is the maintenance of an active market for commodified compliance products, programs, and solutions. The ultimate objective of this game and associated commodities, however, is not corporate crime control. Compliance expenditures are not made with evidence that they will promote employee integrity, change corporate behavior, improve corporate culture, and facilitate ethical corporate decision making. ${ }^{57}$ Companies buy assurance that if and when there is wrongdoing, the entity will be spared. ${ }^{58}$

The public objectives of compliance expenditures are confounded by concerns of firms that a more careful, technology-driven and, indeed, scientific consideration of compliance would result in expectations of voluntary disclosures to regulators and prosecutors. This is a true compliance conundrum. ${ }^{59}$ If one looks at the history of this game in light of

55. See Brandon L. Garrett, Too Big to JaIL: How Prosecutors Compromise with CORPORATIONS (2014) (providing a seminal treatment of firm size and corporate criminal justice); see also Brandon L. Garrett, Structural Reform Prosecution, 93 VA. L. REV. 853 (2007) (giving an insightful review of post-sentencing reforms); Laufer, supra note 7 (discussing the game and its players).

56. See Toni Makkai \& John Braithwaite, Procedural Justice and Regulatory Compliance, 20 L. \& HuM. BEHAV. 83, 95 (1996) ("Perceptions of the fairness of processes are more strongly associated with satisfaction with the regulatory process than are the favorableness of regulatory outcomes.").

57. See David Hess, Ethical Infrastructures and Evidence-Based Corporate Compliance and Ethics Programs: Policy Implications from the Empirical Evidence, 12 N.Y.U. J.L. \& Bus. 317 (2016) (discussing the challenges of evidence-based research).

58. See William S. Laufer, Illusions of Compliance and Governance, 6 CORP. GOVERNANCE 239 (2006) (reviewing firm culpability in relation to the compliance industry).

59. See William S. Laufer, The Missing Account of Progressive Corporate Criminal Law, 14 N.Y.U. J. L. \& BUS. (2017) (discussing the compliance conundrum); see also Susan Lorde Martin, Compliance Officers: More Jobs, More Responsibility, More Liability, 29 Notre DAme J. L. ETHics \& PUB. Pol'y 169 (2015) (detailing the rise of the role of Chief Compliance Officer and the interplay between compliance mandates and failing to comply). 
this conundrum, it is simply a catalog of public stakeholders teasing firms with prescriptive guidelines and then threatening firms in ways that push compliance spending forward with both partners lacking an incentive to assess, evaluate, and actually share compliance data. ${ }^{60}$ Ultimately, this compliance conundrum redounds to public partners who minimize their own costs by not having to look inside the regulatory kitchen, along with a gleefully complicit compliance and ethics industry who take their fair share of the "good citizenship" spending. Knowing the players and rules of this game opens a window into how corporate crime control "partners" maintain an equilibrium, but one that is uncertain in terms of optimality of effective design for deterrence. ${ }^{61}$

It also would be a miscalculation to narrowly look at public cost shifting when thinking about the betrayal of this partnership. There are, of course, a litany of direct and indirect costs. ${ }^{62}$ There are also significant costs and externalities associated with the pretense of promoting good corporate citizenship that encumber stakeholders inside and outside of the partnership. More important, a full accounting recognizes that the costs of this milestone extend beyond a simple function of public versus private sector spending.

\section{The Costs of Chasing the Tail of Good Corporate Citizenship}

How corporate self-regulation matured or failed to mature over time reveals a number of costs and externalities that should be considered in any model of this failed partnership, e.g., a wide range of public losses that are a direct or indirect function of this failure beyond the price paid to meet or exceed the requirements of the regulation itself, and the opportunity costs of employing personnel who, if deployed elsewhere in the organization would be adding business value. These externalities include: (a) regulatory atrophy, i.e., where the kind, capacity, and quality of government

60. See Laufer, supra note 49 (discussing the horse-trading, or shrewd bargaining, in cooperative compliance relationships).

61. See Sally S. Simpson, Melissa Rorie, Mariel Alper, Natalie Schell-Busey, William S. Laufer, \& N. Craig Smith, Corporate Crime Deterrence: A Systematic Review, CAMPBELL Systematic ReViews (May, 2014) (showing, empirically, the deterrent effects of law, punitive damages, and regulatory policies).

62. For a good taxonomy of 18 different direct and indirect costs of regulations affecting the government, citizens and businesses, and consumers and producers, see Wim Marneffe \& Lode Vereeck, The Meaning of Regulatory Costs, 32 EuR. J. L. ECON. 341, 343 (2011) (identifying fifteen direct costs and two indirect costs in an analysis of types of regulatory costs); see also Howell E. Jackson, Variation in the Intensity of Financial Regulation: Preliminary Evidence and Potential Implications, 24 YALE J. ON REG. 253, 253 (2007) (presenting empirical evidence on the magnitude of direct regulatory costs within the financial services industry). 
monitoring, surveillance, and investigatory services, now largely shifted to private firm counterparts, diminishes significantly; (b) firm opacity, i.e., where private sector compliance spending, often in the name of transparency and good citizenship, deftly obscures the identity of compliant and noncompliant firms for regulators exploring possible wrongdoing; (c) reactionary discretion, i.e., where the failure of adequate government investment in regulatory capacity, along with regulatory atrophy, result in either prosecutorial declinations or symbolic prosecutions that may not be in the best interests of the public; (d) stakeholder deception, i.e., where the exercise of regulatory discretion promotes an enforcement facade that convinces stakeholders, including those in foreign jurisdictions, that our brand of enforced self-regulation works well and is fair and deserving of emulation; and (e) compromised priorities, where the costs of betraying partnership responsibilities result in the apportioning of criminal justice expenditures in ways that are inconsistent with stated priorities, and lay consensus of crime seriousness.

It is this last externality that is most symbolic and telling. What is the justification for such disproportionate public versus private investments in regulatory enforcement? Specifically, why does the State assume the order maintenance costs for street crimes and expect the private sector to underwrite the lion's share of equivalent firm costs, including underwriting the complex of due diligence requirements? Is the shifting of costs fair because the private sector can best afford these expenditures? If so, what residual or corresponding private sector policing responsibilities should be reserved for the State and, as important, who keeps tab on the reasonableness of these expenditures? Finally, is there a limit to the State's expectation for underwriting private sector policing and law enforcement?

Answers to these questions will not come from research on lay perceptions of crime seriousness. Study after study show a lay consensus that ranks corporate wrongdoing equally with serious common law offenses. ${ }^{63}$ Answers also will not come from the language of government

63. See Cedric Michel, John K. Cochran, and Kathleen M. Heide, Public Knowledge About White-Collar Crime: An Exploratory Study, 65 CRIME, L. \& Soc. ChAnge 67 (2016) (discussing the results of a study about lay knowledge perception about white-collar crime rather than public opinions revealing that the public bought into myths about the crimes committed by the powerful); Francis T. Cullen, B. G. Link, and C. W. Polanzi, The Seriousness of Crime Revisited: Have Attitudes Toward White Collar Crime Changed? 20 CRIMINOLOGY 83 (1982) (describing the results of a study where participants ranked vignettes describing a street crime scenario to be more serious than a white collar crime scenario); Nicole L. Piquero, S. Carmichael, and Alex R. Piquero, Assessing the Perceived Seriousness of White-Collar and Street Crimes. 54 CRIM. \& DELINQ. 291 (2008) (discussing a study that found that certain white-collar crimes, like embezzlement, were perceived to be more serious when compared to certain street crimes, like handbag theft); S. P. Rosenmerkel, Wrongfulness 
prosecutors and regulators who, like the words of their predecessors, still speak about corporate cases in the most zealous and overly righteous terms. Below, I argue that the difficulty in weighing the value to the State of waging a war on drugs, for example, relative to pursuing a campaign against corporate fraud comes from less-than-obvious lacunae.

The pursuit of a war against drugs is popularly seen as targeting evils worthy of a public enforcement investment, e.g., drug-related crimes, gang violence, drug-related disease and overdose, and organized criminal organizations. ${ }^{64}$ The daily body count of drug-related violence is a dramatic and tragic fixture of inner city life around the United States, from Chicago and Detroit to Baltimore and Washington, D.C. ${ }^{65}$ The immorality of illicit drug use represents to the public a complex but all-too-familiar combination of addiction, disease, unemployment, lost productivity, and crime. The moral coherence of these "costs" sustains a State-sponsored war that continues to this day, remarkably, even with equivocal evidence that waging

and Harmfulness as Components of Seriousness of White Collar Offenses. 17 J. OF CONTEMP. CRIM. JUST. 308 (2001) (discussing a study that adds to the existing notion that breaks down the comparative seriousness perception of white collar and street crime to include notions of morality, harm, and wrongfulness).

64. See Katherine Beckett, Setting the Public Agenda: "Street Crime" and Drug Use in American Politics, 41 Soc. Probs. 425, 427 (1994) (discussing how the framing of the drug problem as a criminal problem justified aggressive law enforcement and criminal justice practices); William N. Elwood, RHETORIC IN THE WAR ON DRUGS: THE TRIUMPHS AND Tragedies of Public Relations (Greenwood Publg. Group 1994) (discussing how public rhetoric branded drug users to the public and how this helped America's drug problem but also negatively impacted minorities); Whitford \& Yates, Policy Signals and Executive Governance: Presidential Rhetoric in the "War on Drugs," 65 J. POL. 995 (2003) (discussing the impact of presidential rhetoric on bureaucratic enforcement behaviors and decisions).

65. See Elizabeth Griffiths and Jorge M. Chavez, Communities, Street Guns and Homicide Trajectories in Chicago, 1980-1995: Merging Methods for Examining Homicide Trends Across Space and Time, 42 CRIMINOLOGY 941,943 (2004) (portraying the concentration of deaths in urban settings and studying murder trends across Chicago's neighborhoods); Emily Goldmann, Allison Aiello, Monica Uddin, Jorge Delva, Karestan Koenen, Larry M. Gant, and Sandro Galea, Pervasive Exposure to Violence and Posttraumatic Stress Disorder in a Predominantly African American Urban Community: The Detroit Neighborhood Health Study, 24 J. TRAUMATIC STRESS 747 (2011) (discussing a study analyzing over a thousand African-Americans in Detroit with their symptoms of PTSD after witnessing traumatic street crimes); Aaron Curry, Carl Latkin, and Melissa Davey-Rothwell, Pathways to Depression: The Impact of Neighborhood Violent Crime on Inner-City Residents in Baltimore, Maryland, USA, 67 Soc. SCI. \& MED. 23 (2008) (describing results of a study that assessed exposure to street crime as it relates to depressive symptoms among residents of Baltimore, Maryland); David M. Altschuler and Paul J. Brownstein, Patterns of Drug Use, Drug Trafficking, and Other Delinquency Among Inner-City Adolescent Males in Washington, D.C., 29 CRIMINOLOGY 589 (1991) (finding that while drugs made youths more likely to commit crimes, it is only a minority of crimes committed that are associated with drugs). 
this war is a success. ${ }^{66}$ There is no equivalent moral coherence when corporate wrongdoing is unpacked. Missing is a compelling portrait of the dramatic impact of corporate culpability and, in particular, a full account that connects wrongful corporate behavior with actual victims. Missing is both disgust and revulsion for corporate wrongdoing, emotions that make the criminal law so very unique. ${ }^{67}$ It sounds trite, but there is no corporate victimology that reflects and elicits moral indignation like that of street crimes.

\section{Moral Indignation and a Missing Corporate Victimology}

Prosecutors and regulators are often long on moral rhetoric about corporate wrongdoing and short on authentic anger and moral indignation. The cries of indignation from left-of-center civil society activists give way to the needs of firms, markets, risk-taking, entrepreneurship, and capitalism. The problem, we are told, is actually one of over-criminalization, metaphysical games with attributions of personhood, and confounding conceptions of culpability. ${ }^{68}$ It seems as if it is simply impossible to muster the kind of moral disapproval necessary to support a sustained campaign against fraud on Wall Street. It is, after all, a tall order to even try to wrestle the main engines of economic growth to the ground.

There is no comparable shortage of indignation, outrage, fear, and anger over street crime. ${ }^{69}$ The politics of conventional crime are moved by a near

66. John J. Donohue III, Benjamin Ewing, and David Peloquin, Rethinking America's Illegal Drug Policy, in Philip J. Cook, Jens Ludwig, and Justin McCrary, Controlling CRIME: STRATEGIES AND TRADEOFFS 215, 270 (2011) (concluding that marijuana and cocaine legalization and decriminalization can reduce overall social costs resulting from the drugs); Christopher J. Coyne and Abigail R. Hall, Four Decades and Counting: The Continued Failure of the War on Drugs, Policy Analysis: Cato Institute (Apr. 12, 2017).

67. See Dan M. Kahan and Martha C. Nussbaum, Two Conceptions of Emotion in Criminal Law, 96 Colum. L. REv. 269,356 (1996) (discussing disgust and stigma as critically important moral features of the criminal law); see also Cass R. Sunstein, Probability Neglect: Emotions, Worst Cases, and Law, 112 YALE L.J. 61, 63 (2002) (arguing that highly publicized, but low probability dangers can lead to irrational legal and regulatory outcomes as a result of public overreaction).

68. David Ronnegard and Manuel Velasquez, On (Not) Attributing Moral Responsibility to Organizations, in Eric W. Orts and N. Craig Smith (eds.), The Moral ResponsibILITY OF FIRMS (2017) (assessing the liability that firms may have, as well as the people running them, in relation to their civil and criminal actions); Eric W. Orts, The Moral Responsibility of Firms: Past, Present, and Future in Eric W. Orts and N. Craig Smith (eds.), The Moral RESPONSIBILITY OF FIRMS (2017).

69. Alyssa Davis, In U.S., Concern About Crime Climbs to 15-Year High, GALLUP (Apr. 6, 2016), http://www.gallup.com/poll/190475/americans-concern-crime-climbs-yearhigh.aspx [https://perma.cc/59YJ-WSZY].

Americans' level of concern about crime and violence is at its highest point in 
insatiable anger over violent crime, fear of drug-related violence, and craving for the incapacitation of "bad guys." 70 The images of hooded thugs, armed drug dealers, and natural born predators cannot compete with the conferenceroom conspiracies of a board's audit committee or the passive managerial winking of senior leadership. ${ }^{71}$ When one thinks about the evils of violent drug cartels and savage terrorist organizations, who is moved by the complicit, if not facilitating, role of one of the largest and most profitable banks in laundering some newfound wealth from cross-border transactions? When one thinks about deeply ingrained predispositions that equate blackness with badness throughout much of the criminal process, there is really nothing comparable in our thinking about corporate deception and complex organizational frauds. ${ }^{72}$ Our sense of being wronged by corporations and their senior agents is taken seriously but does not encourage

15 years. Fifty-three percent of U.S. adults say they personally worry "a great deal" about crime and violence, an increase of 14 percentage points since 2014. This figure is the highest Gallup has measured since March 2001. Americans' worry about drug use has followed the same basic pattern over the last 15 years as worry about crime and violence. Forty-four percent of U.S. adults say they worry a great deal about drug use, up 10 points from the low found in 2014.

Id.

70. See Cass R. Sunstein, Some Effects of Moral Indignation on Law, 33 VT. L. REV. 405,433 (2008) (discussing the effects that "unjustifiably intense indignation" can have on the decisions of legal and political institutions); William S. Laufer, Where is the Moral Indignation over Corporate Crime? in D. Brodowski, M. Esponoza de los Monteros de la Para, K. Tiedmann, and J. Vogel (eds.), Regulating Corporate Criminal LiabiLity (2014).

71. For a classic image of conformance to corporate life, see William H. Whyte, THE ORGANIZATION MAN (1956) (describing in narrative form the life of an ambiguous businessman from his/her early years, education, entering the firm, conforming to the norms of the firm, and then living his/her life in suburbia).

72. Jon Hurwitz and Mark Peffley, Public Perceptions of Race and Crime: The Role of Racial Stereotypes, 41 AM. J. PoL. SCI. 375, 384 (1997) (explaining that "whites who view African-Americans as violent (and lazy) are far more likely to believe them to be guilty of assault," while white-collar crime does not have a similar effect on judgment because "whites do not envision the white-collar crime as a part of the underclass racial stereotype"); J. L. Eberhardt, P.G. Davies, V. J. Purdie-Vaughns, and S. L. Johnson, Looking Deathworthy: Perceived Stereotypicality of Black Defendants Predicts Capital-Sentencing Outcomes. 17 PsYchol. SCI 383 (2006) (explaining a study that found that blacks who commit crimes against whites are more likely to receive the death sentence if they look more stereotypically black, but if the victim was black, the rates for death sentences are not significantly higher for the stereotypically black-looking defendant). For an outstanding review of the issues, see Randall Kennedy, RACE, CRIME, AND THE LAW (1997) (analyzing the impact race has on different facets of the legal system such as the enforcement of laws, composition of juries, punishments, and the war on drugs). For a classic set of scholarly readings, see Darnell F. Hawkins (ed.) Ethnicity, Race, And Crime: Perspectives ACross Time and Place (1995) (discussing the rise of police aggressiveness in 1900 towards immigrants, violence towards African Americans by white lynch mobs, tribal versus federal jurisdiction on Indian lands, and other race-crime associations). 
the kind of emotions necessary to support a fair and reasonable regime of corporate criminal justice. ${ }^{73}$

A corporate victimology would likely reveal layers of victimization across a wide spectrum of stakeholders; reset our perception of corporate culpability in relation to possible sanctions; and correct the misperception that corporate wrongs are somehow less-than-serious wrongs against the State, wrongs against the community, and wrongs against us. ${ }^{74}$ Aligning the measure of corporate culpability in relation to both liability and punishment is the ultimate achievement. ${ }^{75}$ In the absence of corporate victimology, though, criminal justice expenditures go to where the outrage is, where the fear is, and where crime control wars actually earn some real political favor or patronage.

\section{THE Role OF THE STATE IN CORPORATE CRIME SPENDING}

The State does not have a monopoly on the provision of criminal justice services. Recognition must be given to the importance of private for-profit and non-profit agencies, programs, and interventions that make up a private criminal justice. ${ }^{76}$ Moreover, it is clear that civil, administrative, and regulatory actions approach, if not approximate, the corporate criminal law in many ways. ${ }^{77}$ It is, nevertheless, axiomatic that

73. See, e.g., Susan A. Bandes and Jeremy A. Blumenthal, Emotion and the Law, 8 ANNu. REV. L. SOC. SCI. 161, 165-69 (2012) (demonstrating the ability of victim impact statements to undermine the fairness of the criminal justice process because of the emotions they evoke).

74. For a review of the literature, see Dave Whyte, Victims of Corporate Crime, in Sandra Walklate (ed.) HANDBOOK OF Victims AND VICTIMOLOGY 446 (2007) (analyzing corporate crime victimology through such factors like unequal relations of power, safety of food and other manufactured products, and neo-liberal social orders).

75. William S. Laufer, Corporate Bodies and Guilty Minds, 43 EMORY L.J. 647, 708-09 (1994) (making connections between a constructive corporate fault and criminal liability).

76. See, e.g., David A. Sklansky, The Private Police, 46 UCLA L. REV. 1165 (1999) (analyzing the benefits of private policing in terms of economics, constitutional fairness, and the reduction of red tape); Elizabeth E. Joh, The Paradox of Private Policing, 95 J. CRIM. L. $\&$ CRIMINOLOGY 49 (2004) (discussing many benefits and paradoxes of private policing such as how the size of private police forces are over three times as large as the public police units).

77. John C. Coffee, Jr., Paradigms Lost: The Blurring of the Criminal and Civil Law Models-And What Can Be Done About It, 101 YALE L.J. 1875 (1992) (analyzing the overlapping of the criminal and civil law systems and how a framework of behavioral analysis and incentives can be better than a doctrinal one); John C. Coffee, Jr., From Tort to Crime: Some Reflections on the Criminalization of Fiduciary Breaches and the Problematic Line Between Law and Ethics, 19 AM. CRIM. L. REV. 117 (1981) (advocating against the current norm of attaching federal punishments to breach of fiduciary duties and how they should not come into play until state and private action is proven ineffective); Daniel R. Fischel and Alan O. Sykes, Corporate Crime, 25 J. LEgAL STUD. 319 (1996) (advocating for the use of civil 
the public policing function reflects the formality of the modern State as an instrument of social control and the fair exercise of government power. After all, it is the State that reserves the responsibility for conceiving of the role and order maintenance functions of both policing and crime control. $^{78}$ For this reason and others, the allocation of criminal justice expenditures suggests the priority that the State gives to certain kinds of wrongdoing. ${ }^{79}$

\section{A. The State's Ambivalence}

The abrogation of partnership responsibilities by regulators also says something about the relative value to the State of administering the corporate criminal law. There remains a profound and longstanding ambivalence over command and control approaches to regulating corporations, given the inevitable costs to some of the most respected, if not cherished, of all for-profit institutions. Concerns with the direct and collateral costs of corporate prosecution are so significant that, on the margins, they may engender a de facto deference to corporate power. The result of this regulatory deference is best seen in the disconnect between government representations about their vigilance with combatting corporate crime and the actual number of corporate criminal investigations, charges, trials, and convictions. With other government campaigns against drugs and guns, for example, rhetoric underplays the need for and marshalling of criminal justice resources.

A different brand of ambivalence is found in reviews of the many costs of corporate wrongdoing to internal and external stakeholders. It seems that conceiving of corporate wrongdoing as an offense or violation against the State remains a challenge. The focus on harm to shareholders and other collateral "innocents" shifts attention away from thinking of corporate criminality as a violation of shared values, norms, and conventions. Moreover, the centuries-old debate over the locus of wrongdoing in corporations — now whether liability comes from a

remedies to punish corporate crime as criminal punishments are unnecessary).

78. See Lucia Zedner, Policing Before and After the Police: The Historical Antecedents of Contemporary Crime Control, 46 BRIT. J. CRIMINOLOGY 78,78 (2006) ("The institution of the police is synonymous with the modern state and public policing is one of the defining characteristics of state power.").

79. See, e.g., John Hagan, Who Are the Criminals?: The Politics of Crime Policy from the Age of Roosevelt to the Age of Reagan (2010); Nancy E. Marion and Willard M. Oliver, Congress, Crime, and Budgetary Responsiveness: A Study in Symbolic Politics, 20 CRIM. JUST. POL'y REV. 115, 131 (2009) (describing how crime control policies are shaped in ways to secure political favor with the public and are largely symbolic as opposed to substantive). 
responsible corporate officer or a collective intention - complicates and at times confounds the attribution of fault. ${ }^{80}$ Threshold questions remain about corporate moral agency and the appropriateness of corporations as objects of blame. ${ }^{81}$ This ambivalence leaves scant support for the kind of moral indignation from the State that is a condition precedent to the criminalization of corporate behavior.

\section{B. A Genuine Partner in Corporate Crime Control}

What would corporate regulation look like today if we had the benefit of two genuine partners aligned to combat wrongdoing from the start of the good corporate citizenship movement? A creative and unconstrained historical revision of corporate crime control would place us in a very different regulatory world. First, we would not have come close to this very special regulatory milestone if expenditures were not the solitary proxy for good corporate citizenship, if government functionaries had invested in the precepts of responsive-regulatory theory, gradations of increasingly formal regulatory capacity, and if both partners co-developed and deployed compliance systems and technology. This means going beyond simple models to co-regulation to leverage technology in ways that permit "shared regulation." Second, a focus on evidence not expenditures would have led to significant reductions in costs. No doubt having disclosure expectations recognize base rates of deviance also would have changed the trajectory of private sector costs. Finally, making a meaningful effort to connect determinations of both culpability and liability to corporate punishment would have moved firms away from simply pricing out the costs of wrongdoing.

One of the rarely discussed casualties of the missing public partner in corporate crime control is the absence of a functioning international public regulatory regime. Large multinational corporations invest the most in building regulatory capacity, with some constructing sophisticated means of tracking each and every firm transaction across their entire global footprint.

80. See Amy J. Sepinwall, Faultless Guilt: Toward a Relationship-Based Account of Criminal Liability, 54 AM. CRIM. L. REV. 521, 533-34 (2017) (demonstrating that while many might consider punishing a group member because of the misdeeds of another "primitive," there are viable arguments that can support such punishment); Amy J. Sepinwall, Responsible Shares and Shared Responsibility: In Defense of Responsible Corporate Officer Liability, 2014 COLUM. Bus. L. REV. 371 (2014) (analyzing the need and justifications for the existing responsible corporate officer doctrine which can punish corporate officers who may not have been directly involved in the corporate crime).

81. See, e.g., Orts \& Smith, supra note 68 (assessing the liability that firms may have, as well as the people running them, in relation to their civil and criminal actions). 
Governments around the world are dramatically outmatched by the sophisticated algorithms that drive compliance analyses of large data by these firms. The failure of a comparable or even greater investment in public capacity across a wide range of jurisdictions directly contributes to regulatory inconsistencies, inefficiencies, and at times, unfairness. ${ }^{82}$

\section{A Retreat From This Milestone: A Compliance CONVERGENCE}

There are some soon to be realized benefits of this largely one-sided investment in compliance. After many years of unbridled spending, the ingredients are there for a disruption and then transformation in the private sector's investment in compliance science. These changes, I have argued elsewhere, come from an opportunistic convergence of corporate strategy, compliance science, compliance standards, and technology that will significantly reduce compliance-related expenditures while impacting firm culture, leadership, and people. ${ }^{83}$ For the first time, and as a sequelae of the partnership, there are testable GRC models, innovations in risk modeling, measures, metrics, data, analytics, standards, committed compliance professionals, relevant compliance scholarship, and large firm resources dedicated to promote good governance, organizational integrity, and compliance. ${ }^{84}$

82. See David Vogel, The Private Regulation of Global Corporate Conduct: Achievements and Limitations, 49 BuS. \& SoC'Y 68, 73 (2010) (explaining that governments seem unable to regulate businesses' activities due to the structure and scale of global production).

83. See Laufer, supra note 7.

84. See, e.g., Michael Volkov, The Impact of New Technologies in Corporate Governance, Risk Management and Compliance Programs (2013); Tina Balke, Marina De Vos \& Julian Padget, I-ABM: Combining Institutional Frameworks and Agent-Based Modelling for the Design of Enforcement Policies, 21 ARTIFICIAL InTELLIGENCE L. 371, 372 (2013) (introducing formal and empirical models, such as institutional frameworks and agentbased models, to explore policy outcomes); Samson Esayas \& Tobias Mahler, Modeling Compliance Risk: A Structured Approach, 23 ARTIFICIAL InTELligence L. 271, 275 (2015) (suggesting a five-step process as a structured, systematic approach to a graphical modeling of compliance risks); Carole Switzer, Accelerating the Evolution of GRC, 13 COMPLIANCE WK., July 2016, at 70 (explaining that GRC systems can analyze vast amounts of data from systems like email, voice messages, and social media posts, and can provide reports to compliance professionals); The GRC Market is Expanding at an Exponential Rate, LOCKPATH (June 29, 2015), (available at: https://www.lockpath.com/blog/the-grc-market-is-expandingat-an-exponential-rate/ [https://perma.cc/E4D5-JACC]) ("With over 600 GRC solutions on the market currently, it seems that predictions show that the GRC market would hit $\$ 31.77$ billion by the year 2020 with global compliance market spend reaching $\$ 2.6$ billion in 2015 alone"); John Verver, Big Data and GRC, CORPORATE COMPLIANCE Insights (June 21, 2013); see also Anant Kale, Artificial Intelligence: The New Super Power for Compliance, 
This joins enterprise-wide governance, risk, and compliance standards, from the Enterprise Risk Management Standards of the Committee of Sponsoring Organizations (Treadway Commission) (COSO ERM), and the International Organization for Standardization (e.g., ISO 19600, ISO 31000 , and ISO 38500). ${ }^{85}$ This convergence in compliance thinking, standards, analytics, and metrics reflects a new private sector convention in required technology and regulatory orientation.

There is little doubt that this compliance convergence will at some point reduce private sector costs, while facilitating a retreat from this regulatory milestone. The development and sharing of increasingly sophisticated and elaborate RegTech and FinTech models from the United States and across Europe and Australia, for example, suggest that this new global compliance convention is not far away. ${ }^{86}$ This convention, as hinted to earlier, will likely

CORPORATE COMPLIANCE INSIGHTS (Aug. 31, 2016), http://www.corporatecomplianceinsi ghts.com/artificial-intelligence-new-superpower-business-compliance/ [https://perma.cc/2HJY-Q2WH] (proposing that advances in artificial intelligence can improve compliance).

85. See Robert R. Moeller, COSO Enterprise Risk Management: Establishing EFFective Governance, Risk, AND COMPLiance Processes 1-2 (2d ed. 2011) (setting forth an internal control framework that has become the accepted standard across the world); International Organization for Standardization, ISO 19600 (2014), https://www.iso.org/stan dard/62342.html [https://perma.cc/4C9S-3ZGP] (providing guidance for establishing a compliance system within an organization); International Organization for Standardization, ISO 31000 (2009), https://www.iso.org/standard/43170.html [https://perma.cc/DS4E-2HPZ] (providing guidelines on risk management); International Organization for Standardization, 38500 (2008), https://www.iso.org/standard/51639.html [https://perma.cc/NY6H-JJRC] (providing guidance on corporate directors' use of information technology).

86. See, e.g., Lawrence G. Baxter, Adaptive Financial Regulation and RegTech: A Concept Article on Realistic Protection for Victims of Bank Failures, 66 DUKE L.J. 567, 572 (2016) (arguing for technology to be used to update regulation and enable regulators to keep up with evolving markets); Iris H. Chiu, FinTech and Disruptive Business Models in Financial Products, Intermediation and Markets: Policy Implications for Financial Regulators, $21 \mathrm{~J}$. TECH. L. \& POL'Y 55, 56 (2016) (discussing the potential disruption of technology to the traditional financial services industry); C. Andrew Gerlach, Rebecca Simmons \& Stephen Lam, US Regulation of FinTech: Recent Developments and Challenges, J. FIN. TRANSFORMATION, Nov. 2016 at 87,95 (explaining an alternative approach that would allow FinTech companies to work together with regulators); Philip Treleaven, Financial Regulation of FinTech, 3 J. FIN. PERSP. at 14 (2015) (suggesting that the next challenge lies in encouraging regulators, financial institutions, FinTech companies, and others to come together to improve financial regulation); Thomas Philippon, The FinTech Opportunity 15 (Nat'l Bureau of Econ. Research, Working Paper No. 22476 2016) (considering a different approach to regulation that would benefit from the FinTech movement); see also Carla L. Reyes, Moving Beyond Bitcoin to an Endogenous Theory of Decentralized Ledger Technology Regulation: An Initial Proposal, 61 VILL. L. REV. 191, 195 (2016) (advocating the adoption of an endogenous theory of regulation that would consider the unique nature of technology); Cliff Moyce, How Blockchain Can Revolutionize Regulatory Compliance Technology, CORPORATE COMPLIANCE INSIGHTS (Aug. 10, 2016), http://www.corporatecomplianceinsights.com/blockchain- 
turn on the advent of technology that allows for a sharing of data and systems between the regulated and regulators - and among regulators across jurisdictions. As suggested earlier, the hope is that "sharing compliance" models will soon dot the regulatory landscape.

\section{OF PENALTIES, IRONIES, AND EQUIVALENCIES}

One of the strongest arguments against corporate criminal liability turns on its overly burdensome collateral and direct costs. The longstanding neoconservative view is that the costs of corporate criminal liability are far too great, that costs are difficult to contain and control, especially in ways that reasonably correspond to the wrongdoing, and that innocents within and outside the firm are snared and besmirched in ways that are unjustifiably costly. ${ }^{87}$ The focus is on unfairness to shareholders, consumers, and other innocents. This conventional account, though, fails to reveal the more profound meanings of this milestone. Three concluding thoughts attempt to shed some light on our investment in good corporate citizenship. First, it is worthwhile to ask whether regulators and prosecutors justify their neglect because they have simply baked the estimated corporate culpability costs into the price of compliance expenditures. If so, the purchase of compliance expenditures escalating to this milestone may be seen as a passive and preemptive compliance penalty. The second thought considers some of the subtle and not so subtle ironies at the approach of this very special milestone. Finally, after further considering the meaning of private and public spending, it seems reasonable, perhaps overdue, to squarely address the questionable equivalence of street crime and suite crime.

\section{A. A Preemptive Compliance Penalty?}

An admittedly cynical explanation of this one-sided "partnership" is that when government functionaries failed to actively invest in their share of enforced self-regulation, they signaled regular increases in the price of firm due diligence in ways that accommodated their perceptions of the cost of regulatees' base rates of undetected organizational deviance. Knowing the difficulty of gaining access to inculpatory evidence - exacerbated by opting out of active investing and oversight - regulators and prosecutors captured

regulatory-compliance/ [https://perma.cc/SMR9-TVZU] (explaining that blockchain technology has the ability to transform businesses processes).

87. See John Hasnas, The Phantom Menace of the Responsibility Deficit, in THE MORAL RESPONSIBILITY OF FIRMS 89, 102 (Eric W. Orts and N. Craig Smith eds., 2017) (arguing against corporate criminal liability because it imposes vicarious collective punishment, which is unjust). 
up front their estimated value of penalties and sanctions that would have been realized if they had wholly invested in the partnership. If this explains some variance in the regulatory equilibrium, then these expenditures may be thought of as a preemptive compliance penalty.

Regulators and prosecutors are all too aware that they see only a very, very small fraction of all actionable cases. ${ }^{88}$ The vast majority of corporate wrongdoing allegations are not reported, not acted on by management, or handled internally at the firm. ${ }^{89}$ Base rates of wrongdoing by agents are remarkably robust, leaving a significant share of uninvestigated and unadjudicated wrongdoing. ${ }^{90}$

While it is fair to assume that this dark figure of corporate culpability is increasing, the number of regulatory cases and corporate criminal cases have consistently declined. ${ }^{11}$ All of this brings about a healthy share of justice that is not done - undistributed justice. ${ }^{92}$ Increasing the price associated with good corporate citizenship directly addresses the undistributed justice problem. Ramping up the costs of due diligence simply offsets the losses and perceived losses from the growing dark figure of corporate culpability,

88. See, e.g., TracReports, supra note 38 ("Over the FY 2004 - 2014 period, Justice Department records show a total of more than 1.6 million defendants were criminally prosecuted. Fully 99.8 percent of these prosecutions were aimed at individuals; only two tenths of one percent $(0.2 \%)$ - or one in 500 - involved companies.").

89. For domestic and international survey data revealing the referral rate, see ETHICS Resource Center, National Business Ethics Survey of Fortune 500 Employees 13 (2012) ("Unevenness of reporting poses an additional risk for businesses because it suggests a disconnect between employees' values and those of the employer.”); ETHICS \& COMPLIANCE Initiative, Global Business Ethics Survey 18 (2016) (comparing countries' reporting rates of bribery and corruption-related misconduct).

90. A wide range of surveys tend to show base rates of observed misconduct by employees (over the past 12 months) between forty and fifty percent. For example, ECI/ERC data ranged from fifty-one percent in 2000 to forty-one percent in 2013. See ETHICS Resource Center, National Business Ethics Survey of the United States Workforce 20 (2014) ("Surveyed employees said that members of management are responsible for six of every ten instances of misconduct, and they pointed the finger at senior managers in 24 percent of observed rule-breaking.").

91. See TracReports, supra note 38 (concluding that the number of criminal corporate prosecutions by the US Department of Justice has declined by 29\% between 2004 and 2014); TracReports, IRS Auditing of Big Corporations Plummets: Potential Annual Revenue Loss $\$ 15$ Billion (March 15, 2016), http://trac.syr.edu/tracirs/latest/416/ [https://perma.cc/FE4ADR6D] (finding that the IRS has undertaken a significantly reduced number of audits).

92. Undistributed justice, like a "justice remainder," is borrowed from the hard retributive notion of justice left undone. See William S. Laufer \& Nien-he Hsieh, Choosing Equal Injustice, 30 AM. J. CRIM. L. 343, 346 (2003) (explaining that retributivism lies at the heart of unequal justice). The term may be traced to the work of Bernard Williams. See Bernard Williams, Moral LuCK: PhiLOSOPHICAL PAPERS 1973-1980 (1981) (discussing "moral remainder"); see also Sepinwall, supra note 80, at 570 (distinguishing between fault and blame and arguing that a blame standard would bring about more justice). 
e.g., the "blameworthiness" associated with the difference between corporate crimes known to the government and base rates of corporate wrongdoing from self-reports and survey data. ${ }^{93}$

Thinking of compliance expenditures as a preemptive penalty reveals some nuance to the motives of the players in the compliance game beyond the fact that it makes resort to formal adjudication of corporate criminal cases unnecessary to do justice. From the firm's perspective, the costs of compliance are paid as ever-increasing insurance premiums against liability. The idea of a preemptive penalty helps explain why concerns with the moral hazard problem here were largely ignored. From the regulator's line of sight, the complexity and near impenetrability of the corporate form would leave significant undistributed justice but for the collection of an upfront or preemptive compliance penalty.

Conceiving of the compliance game in this way also puts into perspective calls for more individual prosecutions in the wake of the Yates Memorandum, frustrations of the public with symbolic and infrequent use of the corporate criminal law in the aftermath of the Financial Crisis of 2008, and very late evidence-empty criteria offered by the DOJ to evaluate the effectiveness of compliance. Regulators know that there are no accepted evidence-based metrics for what constitutes an effective compliance program more than two decades into this experiment of good corporate citizenship. $^{94}$

Thinking of the game in this way also offers a good explanation for the ambivalence, more generally, concerning corporate criminal law. Through a very simple process of elimination, it seems clear that no stakeholder is truly invested in or committed to the idea of entity liability. ${ }^{95}$ That regulators realized how to use the fear of this kind of criminalization to do justice, while maintaining the appearance of genuine ambivalence with corporate liability, is no small feat.

93. See, e.g., Alberto Alesina \& Francesco Passarelli, Regulation Versus Taxation, 110 J. PUB. ECON. 147, 153 (2014) (examining when people favor a tax over regulation to curb activities that create negative externalities).

94. See Parker \& Nielsen, supra note 41, at 64 (seriously questioning whether evaluation science is up to the task of assessing compliance effectiveness); Danielle E. Warren, Joseph P. Gaspar, \& William S. Laufer, Is Formal Ethics Training Merely Cosmetic? A Study of Ethics Training and Ethical Organizational Culture, 24 Bus. ETHICs Q. 85, 106-08 (2014) (working to identify which factors in an integrity initiative at a large bank contribute to changes in both behavior and culture).

95. See generally Laufer supra note 6 (discussing the history of the good corporate citizenship movement). 


\section{B. Irony and Fairness}

Abolitionists of corporate criminal liability have for years bemoaned the immense costs to innocents and significant externalities of criminal investigations, indictments, prosecutions, and convictions against corporations. ${ }^{96}$ They, and likeminded conservatives, however, missed taking a strong principled position against a regulatory strategy of compliance cost shifting to the private sector that brings us closer to this historic spending milestone. All along, the threat of unfair and burdensome costs did not actually reside with the rare event of corporate criminal liability, a regular target of the private sector's concerns. Rather, the threat of unfair and burdensome costs came from firms taking the regulatory bait that compliance expenditures will insure against liability. There is some irony here, perhaps situational irony, that regulators found a way to make the regulated fear the costs of criminal liability so much that, in the name of due diligence and corporate crime control, they pay an increasingly steep if not exorbitant preemptive penalty. ${ }^{97}$

It is not the seductive nature of corporate spending, however, that is most deserving of any attribution of irony. Consider, instead, that those at greatest risk to assume an unfair burden of corporate criminal costs shareholders and other "innocents" - actually pay as much, if not more, with the historic rise of defensive compliance expenditures. It is quite difficult to square this ex ante burden on innocents with any expressed concerns that criminal liability should be avoided if it entails unjust collateral consequences or the notion that prosecutors must mind collateral damage when considering a corporate prosecution.

Perhaps the ultimate irony is that while corporate wrongdoing does not seem to engender a moral indignation comparable to that of street crime when it comes to culpability, the very idea of a preemptive compliance penalty for corporations encourages a normative discussion of substantive fairness that is quite familiar; for example, considering the fairness of aggressive stop and frisk policing strategies on inner city streets, bail

96. See, e.g., John Hasnas, The Centenary of a Mistake: One Hundred Years of Corporate Criminal Liability, 46 AM. CRIM. L. REV. 1329 (2009) (advocating for the abolition of corporate criminal liability); John Hasnas, The Significant Meaninglessness of Arthur Andersen LLP v. United States, 2004 CATO SuP. CT. REV. 187, 197 (2004-2005) (explaining how costs prevent the enforcement of corporate criminal statutes).

97. See James R. Chelius and Robert S. Smith, Firm Size and Regulatory Compliance Costs: The Case of Workers' Compensation Insurance, 6 J. OF POL'Y ANALYSIS \& MGMT 193, 201 (1987) (describing the effects of high insurance premiums and compliance costs that follow regulations, especially regarding small firms); Millar, supra note 44 (discussing the increased fees associated with compliance with the Sarbanes-Oxley Act). 
decisions that promote the preventive detention of indigent defendants, and policies that allow for the selective incapacitation of high risk delinquents. ${ }^{98}$ There is a comparable anticipatory feature or dimension in corporate regulation that entices some ethicists and philosophers to question "whether in the advance of any harm to any individual, there is any basis in morality for forcing compliance." 99

That this penalty goes to the perceived base rate of wrongdoing, not a speculative assessment of potential or possible wrongdoing, distinguishes and diminishes this fairness concern. This preemptive penalty is not in anticipation of any wrong committed. That said, even if there is an obvious moral basis for "forcing compliance," it becomes a little less obvious as compliance expenditures continue to rise unabated. The time will come when the constraint from compliance-related social controls will make the workplace completely inhospitable. ${ }^{100}$ At some point, even those most progressive or libertarian will conclude that compliance expenditures are far beyond optimal levels to satisfy a deterrence rationale, or so significantly disproportionate as to violate desert-based principles. ${ }^{101}$

\section{Costs and the Equivalency of Streets and Suites}

The choice of promoting criminal versus corporate criminal justice reflects a profound normative and ideological divide. Critical fault lines differentiate the philosophies that justify the imposition of the criminal law;

98. See generally Kenneth R. Feinberg, Selective Incapacitation and the Effort to Improve the Fairness of Existing Sentencing Practices, 12 N.Y.U. REV. L. \& Soc. Change 53 (1983) (justifying a policy of selective incapacitation); Andrew Gelman, Jeffrey Fagan, and Alex Kiss, An Analysis of the New York City Police Department's "Stop-and-Frisk" Policy in the Context of Claims of Racial Bias, 102 J. OF The Am. StAT. Ass'N. 813 (2007) (comparing pedestrian stop rates for racial demographics in NYC); Douglas Husak, Lifting the Cloak: Preventive Detention as Punishment, 48 SAN Diego L. REV. 1173 (2011) (advocating for preventative detention if it can be structured as state criminal law punishment).

99. Edward Soule, Morality And Markets: The Ethics of Government Regulation 83 (2003); see generally Tibor Machan, The Petty Tyranny of Government Regulation, in Rights And Regulation 259 (T. Machan \& M. Bruce Johnson eds., 1983) (proposing the idea that government regulation is morally impermissible and undermines humans' autonomy and rights).

100. See William S. Laufer \& Diana C. Robertson, Corporate Ethics Initiatives as Social Control, 16 J. OF Bus. ETHICS 1029 (1997) (discussing social controls and raising concerns about over controlled, overly compliant work environments).

101. See William S. Laufer \& Alan Strudler, Corporate Intentionality, Desert, and Variants of Vicarious Liability, 37 AM. CRIM. L. REV. 1285 (2000) (arguing for the importance of a desert-based account for corporate criminal liability); see also Laufer, supra note 29 (examining optimal compliance expenditures and the consequence that going beyond them undermines deterrent value). 
theories that explain the criminal law's role in regulating behavior; and answers to some of the most vexing metaphysical questions about culpability and liability. Challenges to the legitimacy of both laws and law enforcement are radically different in the street versus suite context. So, too, are the range of regulatory strategies, remedies, and sanctions. Still, the discrepancy is notable and puzzling. ${ }^{102}$

The approaching milestone of both compliance costs and employment, however, encourages some subtle comparisons and distinctions. For example, the idea that corporate criminal justice may be accomplished, at least in part, with an enforced self-regulatory slight-of-hand has no equivalent in conventional criminal justice. There are many other preemptive efforts at "justice" in the criminal process that raise serious concerns about the timing, calculation, burden, effectiveness, and fairness of this kind of anticipatory penalty. ${ }^{103}$ These interventions, though, are not executed with a slight-of-hand so that the direct and indirect costs are hidden. In the criminal process, the disparate impact of race, ethnicity, and class is so transparent, obvious, well-documented, and longstanding that one might think there is a very generous accommodation to both inequality and injustice. In fact, for some, the open and notorious accommodation to the many costs of inequality defines an entire domain of formal social control, with practices that will likely be tolerated or ignored for another generation or more. ${ }^{104}$

There is accommodation to the costs of corporate criminal justice, as seen in the acceptance of an equilibrium in the compliance game. But this is a game of imagery, posturing, teases, threats, and faux indignation with multiple stakeholders that is largely privately-funded. It is a game played by the most powerful "persons" in the world, against the most elite and capable

102. See Darryl K. Brown, Street Crime, Corporate Crime, and the Contingency of Criminal Liability, 149 U. PA. L. REV. 1295 (2001) (comparing and contrasting criminal liability for street and corporate crime).

103. See Freda Adler, Gerhard O. W. Mueller, \& William S. Laufer, CRIMINOLOGY (9th ed. 2017) (reviewing different interventions across the criminal process).

104. See Marc Mauer, The Fragility of Criminal Justice Reform, 21 Soc. Just. 14 (1994) (examining the decline of criminal justice reform and proposing strategies for future reform). Consider the intransigence of mass incarceration policies and practices. See, e.g., Michelle Alexander, The New Jim Crow: Mass InCARCERATion In THE Age of Colorblindness (2012) (arguing that mass incarceration of African-Americans is evidence that we continue to live in a world where the color of one's skin can be outcome-determinative); Dorothy E. Roberts, The Social and Moral Cost of Mass Incarceration in African American Communities, 56 STAN. L. REV. 1271 (2003) (criticizing mass incarceration for its great racial inequalities by unevenly incarcerating African Americans); Bruce Western and Christopher Wildeman, The Black Family and Mass Incarceration, 621 ThE ANNALs of THE AM. ACAD. OF PoL. AND Soc. SCI. 221 (2009) (describing the growth of the American penal system focusing on racial inequality, its significance, and its social impact on African American families). 
of law enforcement. The costs imposed by this game are often set in reserve and, in the past, not fully paid. ${ }^{105}$ Here, corporations fall from grace for a quarter or, at worst, a fiscal year. ${ }^{106}$ And it is not a game for novices, it is not populated by novices, and all players agree to the opaque rules. From the moral rhetoric used to suggest indignation with corporate deviance to the exemption and diversion of the largest of all firms from the criminal process, the most profound normative concerns with the costs of corporate criminal justice are simply subsumed by the game. No one would ever say the same about our criminal justice system.

The symbolism of this milestone is compelling. How many private and public cops are really necessary for street and suite regulation, and who should pay? ${ }^{107}$ What does the public allocation of resources for criminal justice tell us about what and who matters most? Foundational questions about policing the most powerful and powerless follow. And, finally, this milestone allows for some reflection on how we justify imposing the most formal of social controls, at times final and irreversible, in the absence of evidence-based research. ${ }^{108}$

105. See generally U.S. Gov't Accountability OfF., GAO-04-338, Criminal Debt: Actions Still Needed to Address Deficiencies in Justice's Collection Processes (2004) (discussing an increase in outstanding criminal debt and noting a need to improve the debt collection process); U.S. Gov'T ACCOUNTABILITY OFF., GAO-05-80, CRIMINAL DeBT: Court-Ordered Restitution Amounts Far Exceed Likely Collections for the CRime Victims in SELECTED FinANCIAL FRAUd CASES (2005) (studying five selected debt cases and concluding that only about $7 \%$ of the court ordered restitution was actually collected); U.S. Gov't Accountability OfF., GAO-16-297, Fines, Penalties, And Forfeitures for Violations of FinANCIAL CRIMES AND SANCTIONS REQUiREMENTS (2016) (finding that from 2009-2015, 12 billion dollars in fines were assessed and all but 100 million was collected by federal agencies).

106. See, e.g., Jonathan M. Karpoff \& John R. Lott Jr., The Reputational Penalty Firms Bear from Committing Criminal Fraud, 36 J. OF L. \& ECON. 757 (1993) (analyzing fiscal data over time and proposing that additional criminal penalties are not necessary because reputational costs of corporate fraud are very high). $C f$. Jason R. Pierce, Reexamining the Cost of Corporate Criminal Prosecutions, 20 J. OF MGMT 1 (2015) (finding that criminal prosecutions are correlated with a decline in stock value). But $c f$. Jonathan M. Karpoff, John R. Lott, Jr, \& Eric W. Wehrly, The Reputational Penalties for Environmental Violations: Empirical Evidence, 48 J. OF L. \& ECON. 653 (2005) (examining consequences of environmental violations on firms and determining that environmental violations are disciplined through legal and regulatory penalties rather than reputational).

107. See generally Greg A. Caldeira \& Andrew T. Cowart, Budgets, Institutions, and Change: Criminal Justice Policy in America, 24 AM. J. OF PoL. SCI. 413 (1980) (discussing the history of budgetary appropriations for criminal justice).

108. See Simpson, supra note 61 (reviewing studies of formal legal and administrative control and prevention strategies for corporate criminal activity and determining that more methodologically rigorous studies are necessary since existing studies are limited, inconsistent, and contradictory). 


\section{CONCLUSION}

It is a fair assumption that the regulatory status quo will change with the increasing convergence of global standards with new governance, risk, and compliance methods, technologies, and shared enterprise-wide systems. There is little doubt that this convergence will bring about significant efficiencies and, at the same time, a discernable move away from this very special regulatory milestone. This convergence opens a window for regulators and prosecutors to welcome a new phase of the decades-old good corporate citizenship movement, one that takes seriously their mandate as partners in corporate crime control.

With both private and public partners, the prospects are good that a collaboration on compliance standards, methods, technologies, and science will address the challenges of undistributed corporate criminal justice with transparency and fairness. One day soon, with a successful transition to a more responsive sharing of compliance data and systems across public and private stakeholders, there will be regret by many that we reached this remarkable milestone.

Ideal models to inspire this kind of shared compliance are widely available, from Braithwaite's notion of Regulatory Capitalism to Baldwin and Blacks' Really Responsive Regulation. ${ }^{109}$ Here, we can all imagine a move away from the strictures of command and control regulation to a restructuring of what is public and private, a regulatory reordering that "is accompanied by an increase in delegation, proliferation of new technologies of regulation, formalization of inter-institutional and intra-institutional relations, and the proliferation of mechanisms of self-regulation in the shadow of the state."110

109. See, e.g., John BraithWAite, Regulatory CAPITALism: How It Works, IdEAS For MAKING IT WORK BETTER (2008) (presenting a model of regulatory capitalism and ideas for reform such as responsive regulation); see also David Levi-Faur, The Global Diffusion of Regulatory Capitalism, 598 The AnNAls of THE AM. ACAD. OF Polit. AND Soc. ScI. 12 (2005) (analyzing regulatory capitalism and suggesting that the change in the capitalist economy is understood by privatization, delegation, increased regulation technology, formalized regulation, and increased influence of international experts); J. Black, Decentering Regulation: Understanding the Role of Regulation and Self-Regulation in a "Postregulatory" World, 54 CURR. LEgAL PROBL. 103 (2001) (discussing how an understanding of decentering is necessary for future attempts at regulation); Robert Baldwin \& Julia Black, Really Responsive Regulation, 71 MoD. L. REv. 59, 61 (2008) (proposing that "[w]e argue that to be really responsive regulators have to be responsive not only to the compliance performance of the regulatee, but in five further ways: to the firms' own operating and cognitive frameworks (their 'attitudinal settings'); to the broader institutional environment of the regulatory regime; to the different logics of regulatory tools and strategies; to the regime's own performance; and finally to changes in each of these elements.").

110. Levi-Faur, supra 109, at 13. 
What happens, though, if this growing convergence fails to change the terms of this partnership? What happens if the regulatory status quo is simply too resilient or the compliance game is too attractive to exit? As compliance life in firms becomes more efficient and technology-bound, regulators and prosecutors will be left in increasing darkness. ${ }^{111}$ At the same time, there will be a rapidly-decreasing pool of corporate compliance expenditures to preemptively draw from. With diminishing penalties being paid and stable base rates of wrongdoing, this means more undistributed corporate criminal justice. One can only hope that this motivates both partners to finally join together in pursuing corporate crime control.

111. See Roberta Romano, Regulating in the Dark, in C. Coglianese (ed.) Regulatory BREAKDOWN: THE CRISIS OF CONFIDENCE IN U.S. REGULATION 86, 87 (2012) (discussing how darkness, the unknown, encourages error prone, backward looking regulations that often lag behind private actors); Roberta Romano, Regulating in the Dark and a Postscript Assessment of the Iron Law of Financial Regulation, 43 HoFSTRA L. REV. 25 (2014) (discussing the problem of regulating in the dark without sufficient information, and proposing the inclusion of mechanisms for expert data collection and policy reassessment after a period of time). 